Article

\title{
Isolation and Synthesis of Laxaphycin B-Type Peptides: A Case Study and Clues to Their Biosynthesis
}

\author{
Louis Bornancin 1,+, France Boyaud 1,+, Zahia Mahiout 1, Isabelle Bonnard 1, Suzanne C. Mills ${ }^{2,3}$, \\ Bernard Banaigs ${ }^{1,3, *}$ and Nicolas Inguimbert ${ }^{1, *}$
}

Received: 15 October 2015 ; Accepted: 30 November 2015 ; Published: 5 December 2015

Academic Editor: Vassilios Roussis

1 Centre de Recherche Insulaire et Observatoire de l'Environnement (CRIOBE), USR 3278

EPHE-CNRS-UPVD, Université de Perpignan Via Domitia, 58 avenue P. Alduy, 66860 Perpignan, France; louis.bornancin@wanadoo.fr (L.B.); france.boyaud@gmail.com (F.B.); zahia.mahiout@hotmail.fr (Z.M.); isabelle.bonnard@univ-perp.fr (I.B.)

2 Centre de Recherche Insulaire et Observatoire de l'Environnement (CRIOBE), USR 3278

EPHE-CNRS-UPVD, BP 1013 Papetoai, Moorea, French Polynesia, France; suzanne.mills@univ-perp.fr

3 Laboratoire d'Excellence “Corail”, 58, avenue Paul Alduy, 66860 Perpignan, France

* Correspondence: banaigs@univ-perp.fr (B.B.); nicolas.inguimbert@univ-perp.fr (N.I.); Tel.: +33-430-198-130; Fax: +33-430-198-138

+ These authors contributed equally to this work.

\begin{abstract}
The laxaphyci's B family constitutes a group of five related cyclic lipopeptides isolated from diverse cyanobacteria from all around the world. This group shares a typical structure of 12 amino acids from the L and D series, some of them hydroxylated at the beta position, and all containing a rare beta-amino decanoic acid. Nevertheless, they can be differentiated due to slight variations in the composition of their amino acids, but the configuration of their alpha carbon remains conserved. Here, we provide the synthesis and characterization of new laxaphycin B-type peptides. In doing so we discuss how the synthesis of laxaphycin B and analogues was developed. We also isolate minor acyclic laxaphycins $\mathrm{B}$, which are considered clues to their biosynthesis.
\end{abstract}

Keywords: non ribosomal peptides; cyclic lipopeptide; solid phase peptide synthesis; Anabaena; Lyngbya

\section{Introduction}

Among marine organisms, filamentous cyanobacteria occupy a special place and/or are of great interest for chemists because they produce a wide range of bioactive molecules, mainly cyclic lipopeptides [1-3]. Interestingly, they produce this class of secondary peptide metabolites via a non-ribosomal pathway that is responsible, for example, for the modification of natural amino acids into D-, $N$-methyl, $\beta$-hydroxylated, or dehydrated amino acids. These non-ribosomal peptide synthases (NRPS) are often associated with polyketide synthases (PKS) that allow fatty amino acids to be inserted within the peptide sequence $[4,5]$. The concomitant effects of these two multi-domain enzymes contribute to the vast diversity of structure observed in these secondary cyclopeptide metabolites [6].

Laxaphycins are cyclic lipopeptides synthesized through a hybrid PKS/NRPS biosynthetic pathway by different marine or freshwater cyanobacteria. They contain amino acids of alternate stereochemistry (L or D) and feature a rare fatty $\beta$-amino acid with a linear chain of up to 12 carbons [7]. Several studies have reported structural variants and likely biosynthetic derivatives of laxaphycins that can be separated into two groups, the laxaphycin A-type peptides, whichare cyclic 
undecapeptides, and the laxaphycin B-type peptides, which are cyclic dodecapeptides. Laxaphycin A-type and laxaphycin B-type peptides are generally found in the same cyanobacteria.

Anabaena laxa [8], A. torulosa [9], Lyngbya confervoides [10], Trichormus sp. [11], and cf. Oscillatoria sp. [12] express laxaphycins B, B2, B3, and D, lobocyclamides B and C, and trichormamides B and C. Furthermore a Lyngbya sp. strain produces lyngbyacyclamides A and B [13] (Figure 1). Horizontal gene transfer between cyanobacteria has been suggested as an explanation for the presence of all these closely related compounds in diverse species [14].

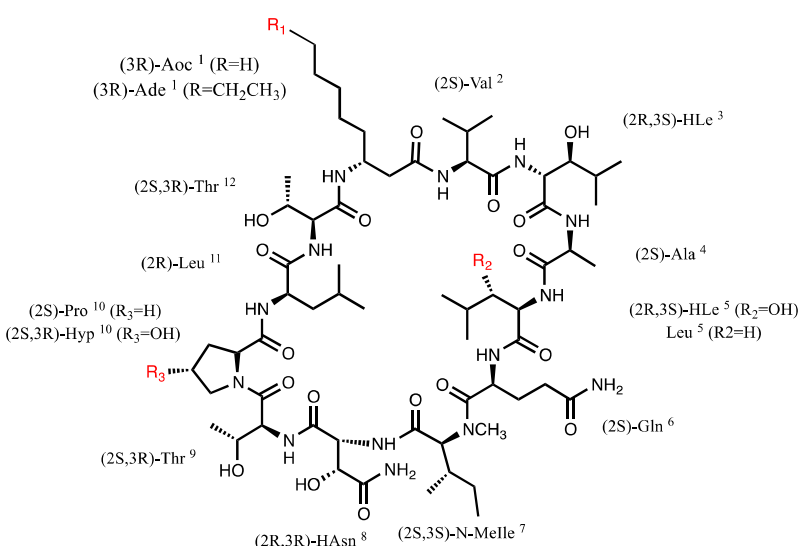

Laxaphycin B [(3R)-Ade ${ }^{1},(2 \mathrm{R}, 3 \mathrm{~S})-\mathrm{Hle}{ }^{5},(2 \mathrm{~S})$-Pro $\left.{ }^{10}\right]$ Laxaphycin B2 [(3R)-Ade ${ }^{1},(2 R)-$ Leu $^{5}$, (2S)-Pro ${ }^{10}$ ] Laxaphycin B3 [(3R)-Ade ${ }^{1},(2 \mathrm{R}, 3 \mathrm{~S})-\mathrm{Hle}^{5}$, (2S,3R)-Hyp ${ }^{10}$ ]

Laxaphycin D [(3R)-Aoc ${ }^{1},(2 \mathrm{R}, 3 \mathrm{~S})-\mathrm{Hle}{ }^{5},(2 \mathrm{~S})-$ Pro $^{10}$ ] [Anabaena cf. torulosa]

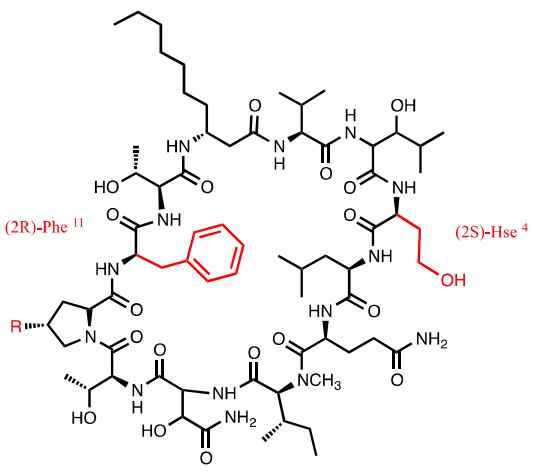

Lyngbyacyclamide $\mathbf{A}[\mathrm{R}=\mathrm{H}]$ Lyngbyacyclamide $\mathbf{B}[\mathrm{R}=\mathrm{OH}]$ [Lyngbya $\mathrm{sp}$.]

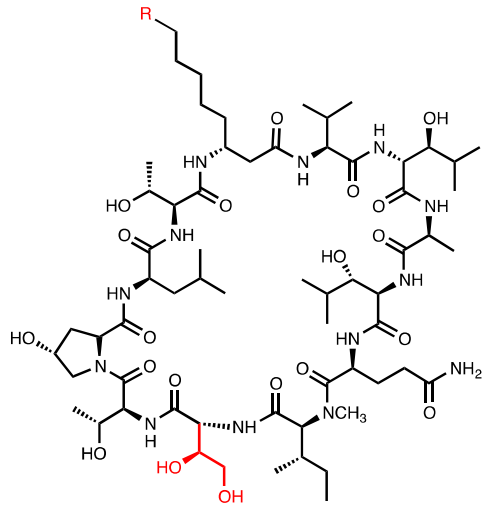

$(2 \mathrm{R}, 3 \mathrm{R})-\mathrm{Htn}^{8}$

Lobocyclamide $B\left[\mathrm{R}=\mathrm{C}_{2} \mathrm{H}_{5}\right]$ Lobocyclamide $\mathbf{C}[\mathrm{R}=\mathrm{H}]$

[Lyngbya confervoides]

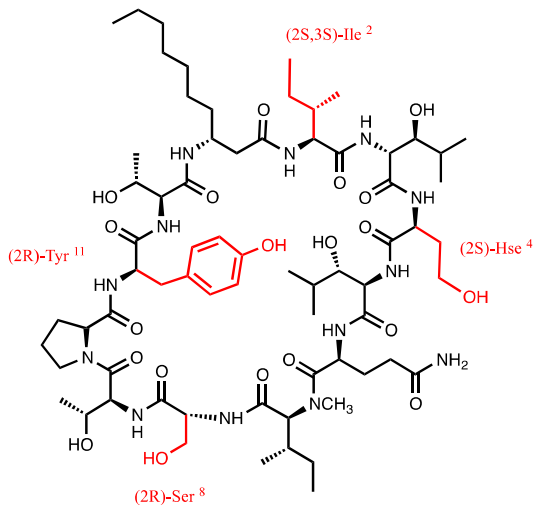

Trichormamide B [Trichormus sp.]

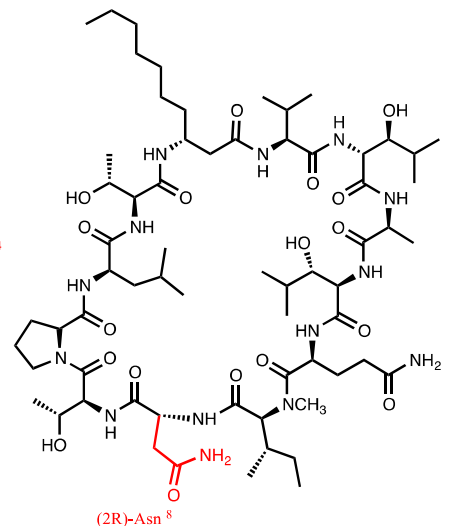

Trichormamide C [cf. Oscillatoria sp.]

Figure 1. Laxaphycins B, B2, B3, and D and their analogs lyngbyacyclamides A-B, lobocyclamides B-C and trichormamides B-C. Differences between laxaphycins and their homologs are highlighted in red.

In the present study we were interested in the study of laxaphycin peptides from A. cf. torulosa, compounds that have already been found to reduce damage by consumers [15]. More specifically, we focus on both total synthesis and structural characterization of laxaphycin B-type peptides; total synthesis being the ultimate way to confirm or revise the proposed structure of such dodecapeptides possessing non-commercial amino acids.

We recently published the first total synthesis of laxaphycin B (short form: laxaB) and lyngbyacyclamide A [16]. Here we describe the synthesis of two new laxaB analogs, including the different steps and strategies that were taken to revise the initially reported structure. We also describe the structure of two new acyclic laxaB-type peptides. The presence of these acyclic 
dodecapeptides, named acyclolaxaphycin B (11) and acyclolaxaphycin B3 (12), together with the other laxaphycins in the extract of $A$. cf. torulosa, provide valuable information for the biosynthesis of laxaphycins. Understanding how these non-ribosomal peptides can be chemically synthesized and how such intriguing structures can be synthesized in nature is challenging.

\section{Results and Discussion}

\subsection{Synthesis of Laxaphycin B Analogs}

The synthesis of lipocyclopeptides of marine origin is not straightforward, firstly because synthetic chemists have to make a choice among the different potential stereochemistry options for the isolated compounds. Secondly, they need to prepare non-natural amino acids and use them sparingly when developing the synthesis or even have recourse to use related analogs, before extending the synthesis to the natural compound. Taking these limitations into account, especially the uncertainty concerning the stereochemistry of the residue in position 3, we proposed an analog of the $\left((2 S, 3 S)-\mathrm{Hl}^{3}\right)$ laxaphycin $\mathrm{B}$, the compound initially described for laxaB, in which the 2-aminodecanoic acid (Ade), the 3-hydroxyleucines (Hle), and the 3-hydroxyasparagine (HAsn) were replaced by the simplest and commercially available $\beta$-alanine, threonine, and asparagine, respectively, leading to analog 1 (Figure 2). The replacement amino acids were selected with respect to the stereochemistry of the alpha carbon of the published compound. These peptides can be obtained either by adopting an in-solution synthetic strategy or by solid phase peptide synthesis (SPPS). Due to its numerous advantages including the avoidance of repetitive purification steps and flexibility, SPPS was used preferentially to the in-solution strategy. Furthermore, we make use of an instrumentation combining the advantages of automation and microwave heating that speeds up synthesis and increases overall yield and purity for difficult peptide sequences [17-20].

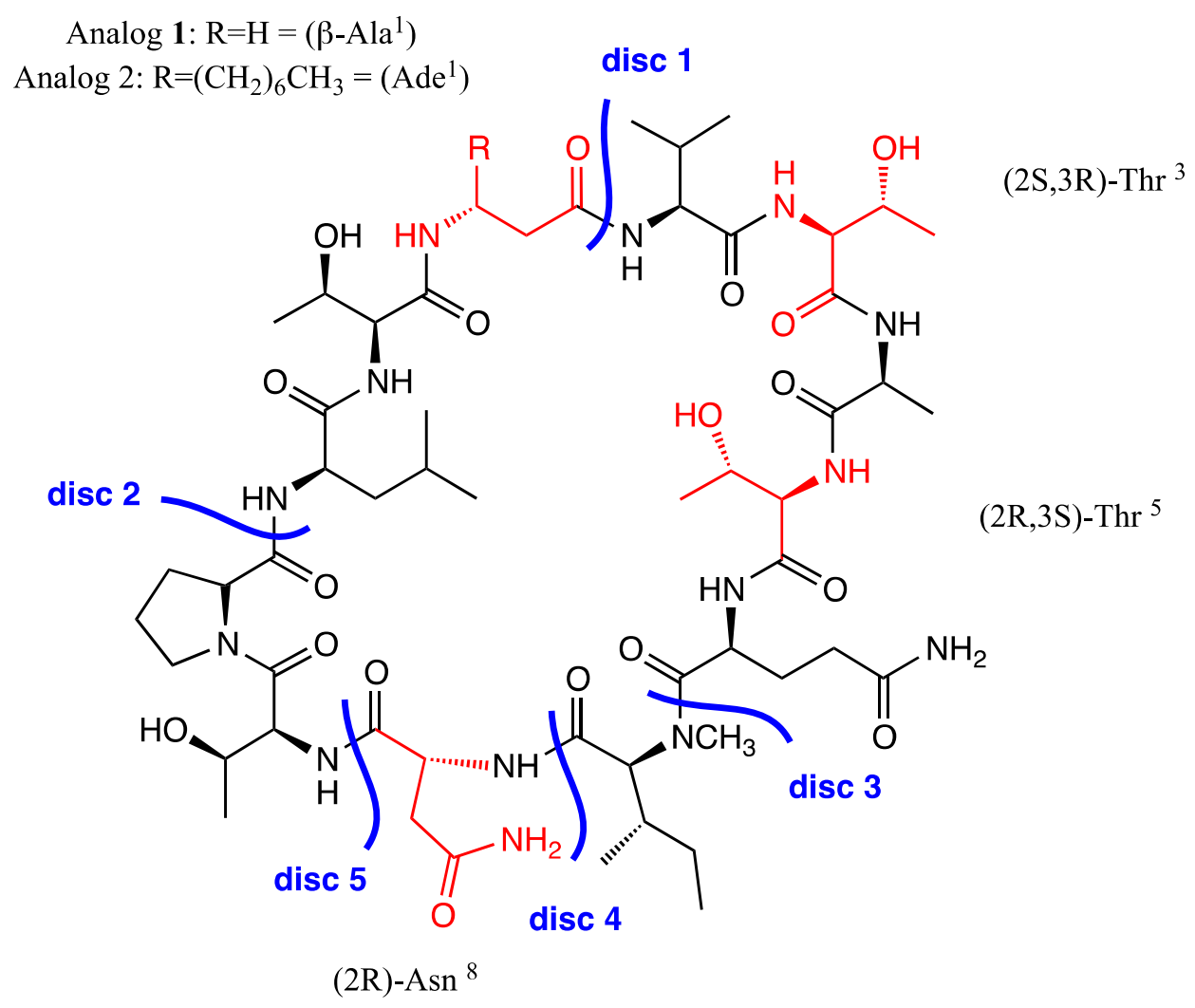

Figure 2. Proposed simplified analogs $\mathbf{1}$ and 2 of $\left[(2 S, 3 S)-\mathrm{Hl}^{3}\right]$ laxaphycin $\mathrm{B}$ and feasible disconnections. 


\subsubsection{Retrosynthetic Analysis of the Laxaphycin B Analog 1}

Five disconnections were envisaged for the cyclization of a linear precursor obtained by a Fmoc/tBu SPPS strategy. Depending on the position of the disconnected amide bond, the cyclization can be performed in solution or on the resin [21]. Thus disconnections 1 and 2 (Figure 2) would imply the use of chlorotrityl resin and a subsequent cleavage in dilute acidic conditions of a completely protected linear peptide that has to be cyclized in solution in the last step. Firstly, this option was discarded because a long reaction time is prone to generate dimerization or oligomerization even in dilute conditions and this option requires sophisticated setups involving syringe pumps to deliver the reagents [22,23]. Secondly, the use of microwave irradiation during peptide elongation was recently shown to be deleterious because of the sensitivity of 2-Cl trityl-resin to extended heating periods [24]. Subsequently, we considered the side chains of an aspartic or a glutamic acid as possible anchoring points onto a low loading Rink amide resin since the final cleavage from the resin would produce the corresponding asparagine or glutamine. Indeed, this would allow the entire synthesis to be performed on the resin due to the temporary allyl protection of the C-terminal $\alpha$-carboxyl-group [25]. Direct use of glutamic acid was inconvenient since the ultimate step of the synthesis, the cyclization, would occur at an impractical coupling site between its carboxylic function and the $\mathrm{N}$-methylated group of the isoleucine (disconnection 3, Figure 2).

Alternatively, we proposed grafting the FmocGlu-N-Melle(Oallyl) dipeptide (3b) on the resin (Figure 2, disconnection 4 ) that was conveniently prepared by successively coupling compounds 4 and 5 using COMU [26] with final deprotection under acidic conditions of the tertiobutylester (Figure 3). Unfortunately, after the addition of the dipeptide onto the resin support and deprotection of the Fmoc protective group, diketopiperazine 6 forms immediately and precludes further extension of the peptide [27]. This was confirmed after acidic release of compound $\mathbf{6}$ from the resin, and analysis of the crude by LC-MS, which showed a major peak with the expected mass $[\mathrm{M}+\mathrm{H}]^{+}$ $m / z 256$.

Finally, among the remaining possibilities our choice was dictated by the presence of the non-commercially available $(2 R, 3 R) \beta-\mathrm{OH}-\mathrm{Asn}^{8}$, a constituent of natural laxaphycin $\mathrm{B}$. In order to test its potential for future use, we had to develop a protocol for its synthesis starting from a surrogate, thus ( $2 R$ )-aspartic acid was chosen as an anchoring point to the resin (disconnection 5). It is noteworthy that one advantage of this strategy resides in the possibility of accessing trichormamide $\mathrm{C}$ analogues.

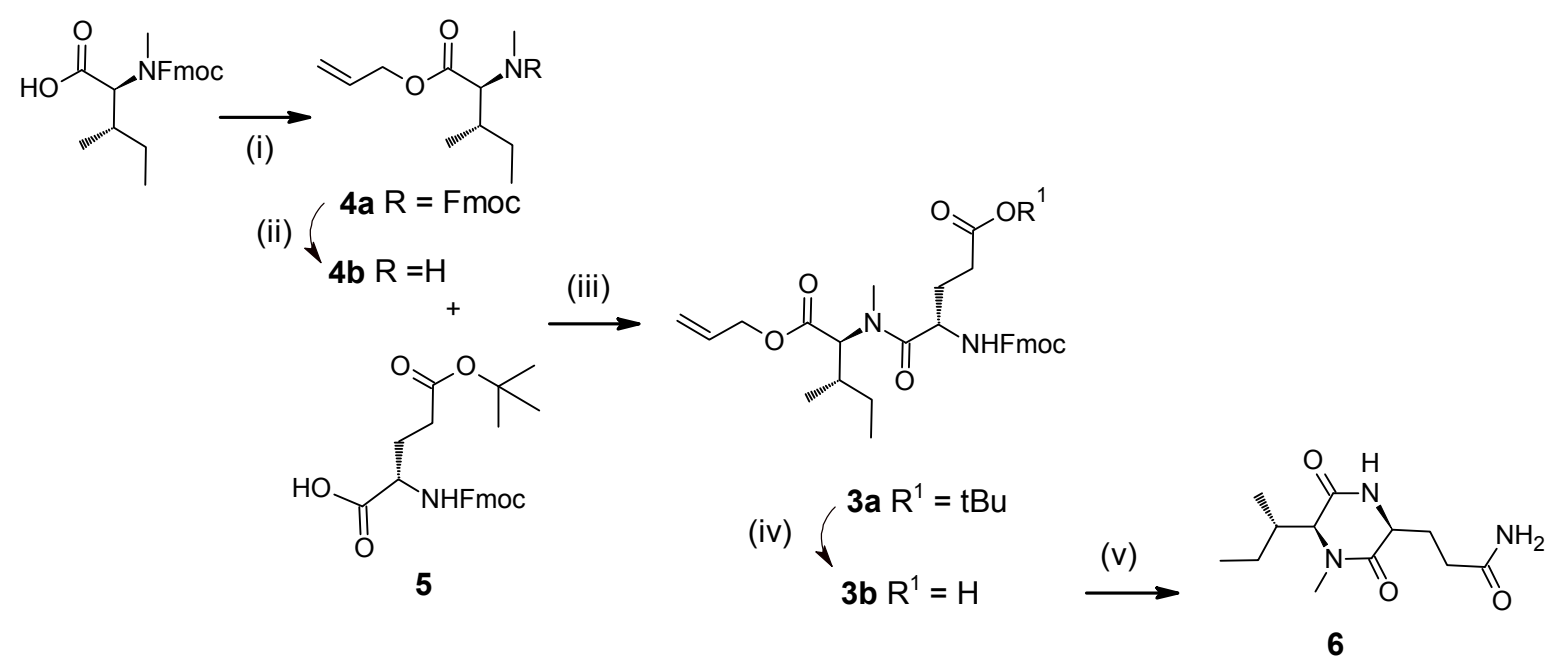

Figure 3. Proposed dipeptide $\mathbf{3 b}$ as a starting material for the synthesis of $\left((2 S, 3 S)-\mathrm{Hl}^{3}\right)$ laxaphycin $\mathbf{B}$ analogs and formation of undesired diketopiperazine 6. Reagents and conditions: (i) $\mathrm{Cs}_{2}\left(\mathrm{CO}_{3}\right)_{2}$, $\mathrm{DMF}$, Allylbromide, 76\%; (ii) piperidine, 70\%; (iii) DIEA, COMU, DMF, 70\%; (iv) TFA, $\mathrm{CH}_{2} \mathrm{Cl}_{2}$; (v) Rink amide resin, HATU, DIEA, piperidine. 


\subsubsection{Solid Phase Synthesis Preliminary Assay of ((2S,3S)-Hle 3$)$ laxaphycin B Analogs}

The ((2S,3S)-Hle $)$ laxaphycin B analog 1 was assembled by stepwise SPPS starting with the introduction of the $N$-Fmoc-aspartic acid $\alpha$-allyl ester onto a low loading rink amide MBHA resin $(0.36 \mathrm{mmol} / \mathrm{g})$ using the effective 2-(7-aza-1H-benzotriazole-1-yl)-1,1,3,3-tetramethyl uronium hexaflurorophosphate HATU as a coupling reagent and a fivefold excess of standard amino acids with regard to resin capacity (Figure 4). The choice of this relatively expensive reagent was guided by preliminary results, which revealed the presence of a difficult coupling site located at the Gln and $\mathrm{N}$-Me-Ile junction, requiring a triple coupling and a capping step. After synthesis of the linear precursor 7, the $\alpha$-carbonyl allyl protecting group of Asn was removed using $\mathrm{Pd}\left(\mathrm{PPh}_{3}\right) 4$. Head to tail cyclization of the resin-bound peptide was accomplished after Fmoc removal using DIC/oxyma $(3 \times 15 \mathrm{~min})$, a base-free condition known to reduce epimerization [28]. Final acidic cleavage followed by HPLC-purification produced the desired peptide $\mathbf{1}$ (Tables 1 and S1).

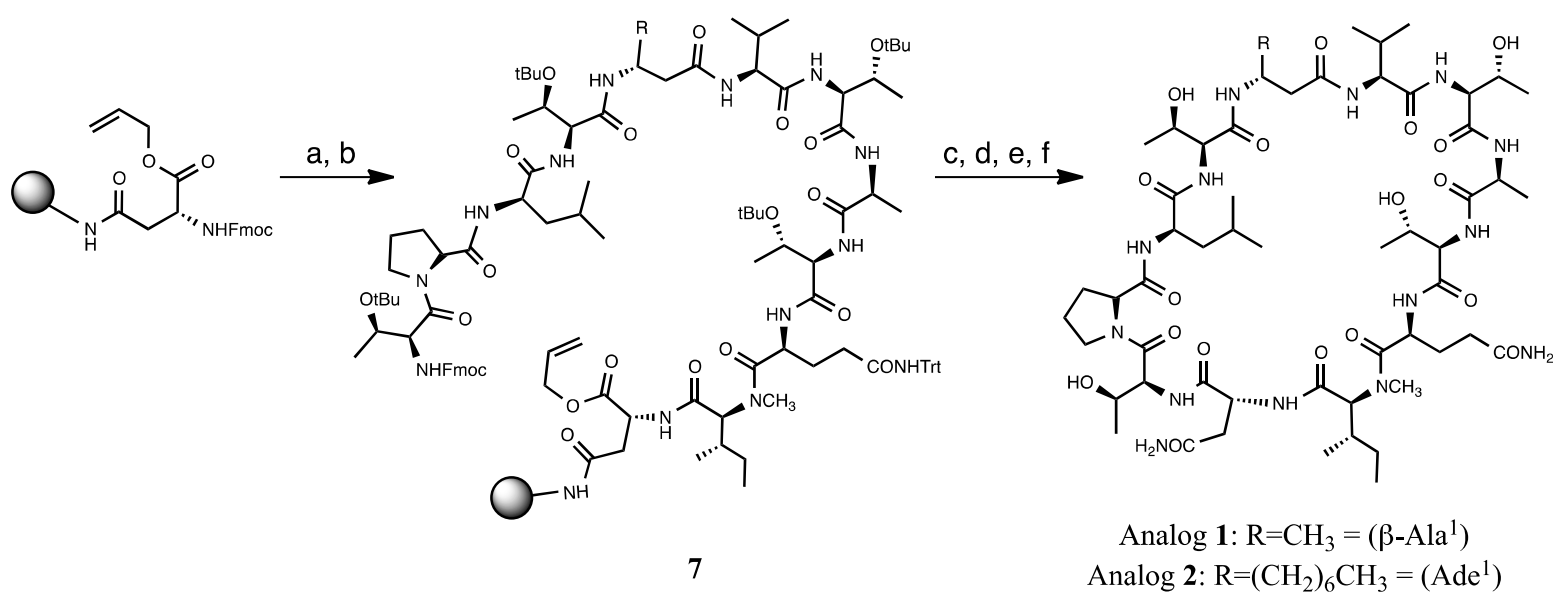

Figure 4. Syntheses of the laxaphycin B analogs 1 and 2. Reagents and conditions: (a): (i) 20\% v/v piperidine, DMF (ii) Fmoc-N-MeIle, HATU, DMF, MW $25 \mathrm{~W}, 70{ }^{\circ} \mathrm{C}, 5 \mathrm{~min}$; (b) repetition of conditions (i) and (ii) for Fmoc-Gln-(Trt) $2 \times 10 \mathrm{~min}$, Fmoc-D-Thr(tBu)-OH, Fmoc-Ala-OH, Fmoc-Thr(tBu)-OH, Fmoc-Val-OH, Fmoc- $\beta$-Ala-OH or Fmoc Ade $2 \times 10$ min, Fmoc-Thr(tBu)-OH, Fmoc-D-Leu-OH, Fmoc-Pro-OH, Fmoc-Thr(tBu)-OH; (c) Pd(PPh3)4, $\mathrm{CHCl}_{3} / \mathrm{AcOH}_{4} \mathrm{NMM}, 3.7 / 0.2 / 0.1$, $v / v / v$ (d) $20 \% v / v$ pipéridine, DMF, rt, $2 \times 2 \mathrm{~min}$ (e) DIC, oxyma, DMF, MW $25 \mathrm{~W}, 70{ }^{\circ} \mathrm{C} 3 \times 15 \mathrm{~min}$; (f) TFA/TIS/H2O 9.5/0.25/0.25, v/v/v, TA, 3 h.

Table 1. Retention time (Rt) in minutes and observed mass peaks of the analogs 1, 2, 8, and laxaB.

\begin{tabular}{ccccc}
\hline Compound & $\mathbf{1}$ & $\mathbf{2}$ & $\mathbf{( ( 2 S , 3 S ) - H l e u ^ { 3 } ) \text { laxa B (8) }}$ & Laxaphycin B (9) \\
\hline Mass Peaks & {$[\mathrm{M}+\mathrm{H}]^{+} m / z 1225$} & {$[\mathrm{M}+\mathrm{H}]^{+} m / z 1323$} & {$[\mathrm{M}+\mathrm{H}]^{+} m / z 1395$} & {$[\mathrm{M}+\mathrm{H}]^{+} m / z 1395$} \\
\hline Rt (min) & 8.64 & 16.01 & 16.3 & Natural: 14.8 \\
& & & & Synthetic: 14.8 \\
\hline
\end{tabular}

The next step on the way to laxaphycin B synthesis was the introduction of the (2R)-2-aminodecanoic acid (Ade) obtained using an already described procedure and subsequent protection with a Fmoc group [29]. Indeed, due to the high hydrophobic character of both Ade and the peptide itself, aggregation of the peptide growing chain was expected even if counterbalanced by microwave irradiation [17]. As expected, a drop in the coupling efficacy of Ade was observed by UV monitoring of the Fmoc group deprotection and was corrected for with a double coupling procedure. Thus analog 2 was obtained and characterized by ${ }^{1} \mathrm{H}-\mathrm{NMR}$ and LC-MS analysis (Tables 1 and S1).

${ }^{1} \mathrm{H}-\mathrm{NMR}$ COSY experiments allowed the chemical shift of all amino acids to be assigned, but ambiguity remained for the four threonines that could not be distinguished. Nevertheless, a 
comparison of NMR spectra of the closely related analogs $\mathbf{1}$ and $\mathbf{2}$ revealed considerable consistency in the observed chemical shift (Figures S1 and S2).

\subsubsection{Laxaphycin B Revised Structure}

Finally, as recently reported, the above synthesis method was applied to laxaB [16]. Briefly, after introduction of the rare (2R,3R)-Fmoc- $\beta$-hydroxyaspartic $\alpha$-allyl ester, (2R,3S)-Fmoc-Hle-(OTBDMS)-OH and (2S,3S)-Fmoc-Hle-(OTBDMS)-OH, 3 mg of pure peptide (8) was obtained [30,31]. The recorded molecular mass of $[\mathrm{M}+\mathrm{H}]^{+} \mathrm{m} / z 1395$ and $[\mathrm{M}+\mathrm{Na}]^{+} \mathrm{m} / z 1417$ from LC-MS ESI+ analysis corresponds to the one expected for laxaB. Nevertheless, a comparison of the retention time of compound (8) with a natural sample of laxaB (9) revealed differences that were further confirmed by co-injection (Table 1) and comparison of NMR spectra. Thus, we could conclude from this experiment that the synthesized compound (8) is a diastereoisomer of laxaB (9). In a last effort to obtain the natural compound, we hypothesized that the hydroxyleucines must have the same configuration as observed for lobocyclamide B. Repetition of the developed synthesis method using (2R,3S)-Fmoc-Hle-(OTBDMS)-OH produced, after purification, $3 \mathrm{mg}$ of peptide 9 co-eluting with laxaphycin $\mathrm{B}$ and presenting the same ${ }^{1} \mathrm{H}-\mathrm{NMR}$ and mass spectra as the natural compound.

\subsection{New Natural Acyclolaxaphycin B Analogs}

Collection and extraction of $A$. cf torulosa and initial separation of the organic extract were described in a previous paper [9]. Further examination of the more polar flash chromatography fractions obtained from the organic extract, by C18 RP HPLC yielded two HPLC pure peaks, acyclolaxaphycin B (short form: acyclolaxaB) and acyclolaxaphycin B3 (short form: acyclolaxaB3). AcyclolaxaB (2 mg) and acyclolaxaB3 (3 mg) were obtained as colorless amorphous solids and responded positively to a ninhydrin test suggesting a non-blocked $\mathrm{N}$-terminus. LC-MS analysis of pure compounds with electrospray positive ionization revealed two different peptides whose $\mathrm{m} / \mathrm{z}$ values are 18 units higher than both laxaphycins B (9) and B3 (10).

\subsubsection{Acyclolaxaphycin B (11): Structure Elucidation}

High-resolution electrospray ionization mass spectrometry (HRESIMS) analysis yielded an $[\mathrm{M}+\mathrm{H}]^{+}$pseudomolecular ion at $m / z 1413.8595$ for a molecular formula of $\mathrm{C}_{65} \mathrm{H}_{116} \mathrm{~N}_{14} \mathrm{O}_{20}$ that was supported by NMR spectroscopic analysis. A comparison with laxaphycin B $\left(\mathrm{C}_{65} \mathrm{H}_{114} \mathrm{~N}_{14} \mathrm{O}_{19}\right)$ revealed that this corresponds to a gain of $\mathrm{H}_{2} \mathrm{O}$.

In the ${ }^{1} \mathrm{H}-\mathrm{NMR}$ spectrum of acyclolaxaB (11), recorded at $500 \mathrm{MHz}$ in DMSO- $d_{6}$, the close structural relationship between the two peptides was clear; the spectrum exhibited, in the $\mathrm{NH}$ proton region, signals typical for $\mathrm{CONH}_{2}$ protons corresponding to $\mathrm{Gln}\left(2 \mathrm{bs}, \delta_{\mathrm{H} 6.79}\right.$, and $\left.\delta_{\mathrm{H}} 7.14\right)$ and

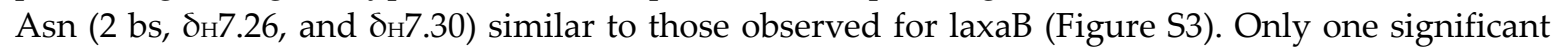
difference was found in the $\mathrm{NH}$ proton region: nine $\mathrm{NH}$ doublets and one large singlet $(2 \mathrm{H})$ were visible in acyclolaxaB ${ }^{1} \mathrm{H}-\mathrm{NMR}$ spectrum, instead of the $10 \mathrm{NH}$ doublets observed between 7.4 and $8.4 \mathrm{ppm}$ for laxaB.

Almost all ${ }^{1} \mathrm{H}$ and ${ }^{13} \mathrm{C}$ resonances of acyclolaxaB (Table 2) could be assigned using extensive 2D NMR analysis including COSY, TOCSY, HSQC, HSQC-TOCSY, and ROESY (Figures S4-S7).

Initially, spin systems in TOCSY spectrum were identified starting from the signals of the backbone amide protons in the region 8.5 to $6.5 \mathrm{ppm}$. From the characteristic chemical shift and comparison with laxaB, eight amino acids could be identified as Hle (2×), Gln, Val, Leu, Thr (2×), and HAsn. A $\beta$-Ade residue system was identified starting from a doublet at $7.53 \mathrm{ppm}$ and possessing an $\mathrm{AA}^{\prime} \mathrm{BB}^{\prime}$ spin system (2.27 and $2.38 \mathrm{ppm}$ ) with additional signals at 4.05, 1.34-1.40, then 1.20-1.23 ppm. One spin system lacking an amide proton was identified as $\mathrm{N}$-Melle due to the correlations of its $\mathrm{H} \alpha$ and $\mathrm{H} \beta$ at 4.71 and $1.91 \mathrm{ppm}$, respectively. One last amino acid, attributed to Ala residue, was identified starting from a broad singlet (two protons) at $8.04 \mathrm{ppm}$, to $\mathrm{H} \alpha\left(\mathrm{\delta}_{\mathrm{H}} 4.03,1 \mathrm{H}\right.$, overlapped bs) and $\mathrm{H} \beta(\delta \mathrm{H} 1.36,3 \mathrm{H}, \mathrm{d})$. 
Table 2. ${ }^{1} \mathrm{H}$ and ${ }^{13} \mathrm{C}$ NMR data for laxaphycins B and B3 and acyclolaxaphycins B and B3 in DMSO- $d_{6}$.

\begin{tabular}{|c|c|c|c|c|c|c|c|c|}
\hline & \multicolumn{2}{|c|}{ Laxaphycin B } & \multicolumn{2}{|c|}{ Acyclolaxaphycin B } & \multicolumn{2}{|c|}{ Laxaphycin B3 } & \multicolumn{2}{|c|}{ Acyclolaxaphycin B3 } \\
\hline & ${ }^{13} \mathrm{C}$ & ${ }^{1} \mathbf{H}$ & ${ }^{13} \mathrm{C}$ & ${ }^{1} \mathbf{H}$ & ${ }^{13} \mathrm{C}$ & ${ }^{1} \mathbf{H}$ & ${ }^{13} \mathrm{C}$ & ${ }^{1} \mathbf{H}$ \\
\hline \multicolumn{9}{|l|}{$\beta \operatorname{Ade}^{1}$} \\
\hline $\mathrm{NH}$ & - & 7.58 & - & 7.53 & - & 7.52 & - & 7.53 \\
\hline $\mathrm{C} \alpha \mathrm{H}_{2}$ & 40.28 & $2.33 / 2.40$ & 40.52 & $2.27 / 2.38$ & - & $2.30 / 2.44$ & 40.42 & $2.28 / 2.40$ \\
\hline $\mathrm{C} \beta \mathrm{H}$ & 45.93 & 4.11 & 46.27 & 4.05 & 45.92 & 4.08 & 46.13 & 4.05 \\
\hline $\mathrm{C} \gamma \mathrm{H}_{2}$ & 33.45 & $1.29 / 1.40$ & 33.62 & $1.34 / 1.40$ & 33.41 & 1.40 & 33.49 & $1.33 / 1.40$ \\
\hline${\mathrm{C} \delta \mathrm{H}_{2}}_{2}$ & $28.67^{*}$ & 1.24 & 28.77 & 1.23 & $28.69 *$ & 1.24 & 28.69 & 1.21 \\
\hline $\mathrm{C}_{\varepsilon} \mathrm{H}_{2}$ & $28.47^{*}$ & 1.20 & 28.61 & 1.20 & $28.47^{*}$ & 1.20 & 28.53 & 1.21 \\
\hline $\mathrm{C} \zeta \mathrm{H}_{2}$ & $25.18^{*}$ & 1.20 & 25.28 & 1.21 & 25.22 * & 1.20 & 25.20 & 1.22 \\
\hline $\mathrm{C} \mathrm{H}_{2}$ & 31.11 * & 1.20 & 31.22 & 1.21 & 31.10 * & 1.20 & 31.15 & 1.20 \\
\hline $\mathrm{C} \mathrm{H}_{2}$ & $21.92 *$ & 1.20 & 22.04 & 1.20 & $21.92 *$ & 1.20 & 21.97 & 1.24 \\
\hline $\mathrm{ClH}_{3}$ & 13.79 & 0.84 & 13.91 & 0.85 & 13.79 & 0.82 & 13.81 & 0.83 \\
\hline $\mathrm{CO}$ & 171.14 & - & 170.30 & - & 171.30 & - & 170.15 & - \\
\hline \multicolumn{9}{|l|}{$\mathrm{Val}^{2}$} \\
\hline $\mathrm{NH}$ & - & 8.18 & - & 7.89 & - & 8.10 & - & 7.89 \\
\hline $\mathrm{C} \alpha \mathrm{H}$ & 59.03 & 4.09 & 57.64 & 4.30 & 58.89 & 4.12 & 57.50 & 4.31 \\
\hline $\mathrm{C} \beta \mathrm{H}_{2}$ & 29.33 & 1.97 & 30.59 & 2.02 & 29.37 & 1.98 & 30.51 & 2.02 \\
\hline $\mathrm{C} \gamma \mathrm{H}_{3}$ & 18.80 & 0.91 & 18.85 & 0.93 & 18.56 & 0.88 & 18.89 & 0.93 \\
\hline $\mathrm{C}^{\prime} \mathrm{H}_{3}$ & 18.87 & 0.85 & 18.95 & 0.81 & 18.85 & 0.84 & 18.78 & 0.81 \\
\hline $\mathrm{CO}$ & 171.05 & - & 171.27 & - & 171.30 & - & 171.15 & - \\
\hline \multicolumn{9}{|l|}{$\mathrm{HLe}^{3}$} \\
\hline $\mathrm{NH}$ & - & 7.94 & & 7.69 & - & 7.90 & - & 7.70 \\
\hline $\mathrm{C} \alpha \mathrm{H}$ & 55.23 & 4.34 & 54.30 & 4.44 & 55.15 & 4.37 & 54.21 & 4.44 \\
\hline $\mathrm{C} \beta \mathrm{H}$ & 76.37 & 3.49 & 76.06 & 3.53 & 76.48 & 3.50 & 76.13 & 3.53 \\
\hline $\mathrm{OH}$ & - & 4.94 & - & - & - & 4.90 & - & - \\
\hline $\mathrm{C} \gamma \mathrm{H}$ & 30.54 & 1.58 & 30.68 & 1.51 & 30.57 & 1.60 & 30.84 & 1.52 \\
\hline $\mathrm{C}_{3} \mathrm{H}_{3}$ & 19.22 * & 0.89 & 19.19 & 0.91 & 18.76 * & 0.89 & 19.23 & 0.91 \\
\hline $\mathrm{C}^{\prime} \mathrm{H}_{3}$ & 18.56 & 0.76 & 18.74 & 0.76 & 18.43 & 0.76 & 18.67 & 0.76 \\
\hline $\mathrm{CO}$ & 171.35 & - & 172.40 & - & - & - & 172.34 & - \\
\hline \multicolumn{9}{|l|}{$\mathrm{Ala}^{4}$} \\
\hline $\mathrm{NH} / \mathrm{NH}_{2}$ & - & 7.86 & - & 8.04 & - & 7.87 & - & 8.05 \\
\hline $\mathrm{C} \alpha \mathrm{H}$ & 49.28 & 4.22 & 48.30 & 4.03 & 49.30 & 4.22 & 48.20 & 4.04 \\
\hline $\mathrm{C} \beta \mathrm{H}_{3}$ & 17.55 & 1.31 & 17.43 & 1.36 & 17.65 & 1.32 & 17.38 & 1.36 \\
\hline $\mathrm{CO}$ & 172.33 & - & 170.02 & - & 172.47 & - & 169.87 & - \\
\hline \multicolumn{9}{|l|}{$\mathrm{HLe}^{5}$} \\
\hline $\mathrm{NH}$ & - & 7.69 & - & 8.34 & - & 7.61 & - & 8.37 \\
\hline $\mathrm{C} \alpha \mathrm{H}$ & 55.52 & 4.28 & 55.40 & 4.44 & 55.64 & 4.28 & 55.27 & 4.46 \\
\hline $\mathrm{C} \beta \mathrm{H}$ & 75.80 & 3.49 & 76.21 & 3.53 & 75.78 & 3.48 & 75.94 & 3.53 \\
\hline $\mathrm{OH}$ & - & 5.03 & - & - & - & 5.05 & - & - \\
\hline $\mathrm{C} \gamma \mathrm{H}$ & 29.90 & 1.56 & 30.65 & 1.51 & 29.84 & 1.58 & 30.73 & 1.51 \\
\hline $\mathrm{C}_{3} \mathrm{H}_{3}$ & $18.65 *$ & 0.89 & 17.58 & 0.82 & 18.69 * & 0.88 & 19.14 & 0.83 \\
\hline $\mathrm{Cd}^{\prime} \mathrm{H}_{3}$ & 18.56 & 0.76 & 19.28 & 0.81 & - & 0.74 & 17.52 & 0.83 \\
\hline $\mathrm{CO}$ & 170.50 & - & 169.74 & - & 170.60 & - & 169.64 & - \\
\hline \multicolumn{9}{|l|}{ Gln 6} \\
\hline $\mathrm{NH}$ & - & 7.77 & - & 8.02 & - & 7.56 & - & 8.04 \\
\hline $\mathrm{C} \alpha \mathrm{H}$ & 49.16 & 4.63 & 48.94 & 4.69 & 49.40 & 4.58 & 48.78 & 4.70 \\
\hline $\mathrm{C} \beta \mathrm{H}_{2}$ & 26.39 & $1.75 / 1.97$ & 26.90 & $1.76 / 1.93$ & - & $1.64 / 2.00$ & 26.86 & $1.77 / 1.94$ \\
\hline $\mathrm{C} \gamma \mathrm{H}_{2}$ & 30.72 & $2.04 / 2.10$ & 30.63 & 2.12 & - & $2.15 / 2.23$ & 30.70 & 2.13 \\
\hline
\end{tabular}




\begin{tabular}{|c|c|c|c|c|c|c|c|c|}
\hline CON & 174.60 & - & 174.38 & - & 174.74 & - & 174.31 & - \\
\hline $\mathrm{NH}_{2}$ & - & $6.85 / 7.22$ & - & $6.79 / 7.14$ & - & 6.79/7.17 & - & $6.80 / 7.16$ \\
\hline $\mathrm{CO}$ & 172.49 & - & 172.45 & - & 172.64 & - & 172.27 & - \\
\hline \multicolumn{9}{|c|}{ N-MeIle ${ }^{7}$} \\
\hline $\mathrm{NCH}_{3}$ & 30.03 & 2.97 & 30.24 & 2.97 & 30.15 & 3.01 & 30.20 & 2.98 \\
\hline $\mathrm{C} \alpha \mathrm{H}$ & 59.85 & 4.72 & 59.94 & 4.71 & 59.87 & 4.73 & 59.79 & 4.73 \\
\hline $\mathrm{C} \beta \mathrm{H}$ & 31.56 & 1.90 & 31.50 & 1.91 & 31.80 & 1.90 & 31.41 & 1.92 \\
\hline $\mathrm{C} \gamma \mathrm{H}_{2}$ & 23.88 & $0.89 / 1.29$ & 23.98 & $0.87 / 1.28$ & - & $0.74 / 1.27$ & 23.92 & $0.87 / 1.27$ \\
\hline $\mathrm{C} \gamma^{\prime} \mathrm{H}_{3}$ & 15.08 & 0.76 & 15.25 & 0.78 & 14.99 & 0.74 & 15.21 & 0.79 \\
\hline${\mathrm{C} \delta \mathrm{H}_{3}}_{3}$ & 10.33 & 0.78 & 10.48 & 0.79 & 10.31 & 0.75 & 10.41 & 0.78 \\
\hline $\mathrm{CO}$ & 170.02 & - & 169.66 & - & 170.10 & - & 169.47 & - \\
\hline \multicolumn{9}{|l|}{ HAsn $^{8}$} \\
\hline $\mathrm{NH}$ & - & 7.64 & - & 7.41 & - & 7.66 & - & 7.41 \\
\hline $\mathrm{C} \alpha \mathrm{H}$ & 55.52 & 4.63 & 55.22 & 4.67 & 55.53 & 4.63 & 55.13 & 4.71 \\
\hline $\mathrm{C} \beta \mathrm{H}$ & 70.44 & 4.31 & 71.04 & 4.36 & 70.33 & 4.35 & 70.99 & 4.37 \\
\hline $\mathrm{OH}$ & - & 5.79 & - & 5.78 & - & 5.70 & - & - \\
\hline $\mathrm{CON}$ & 173.37 & - & 173.20 & - & 173.37 & - & 173.20 & - \\
\hline $\mathrm{NH}_{2}$ & - & 7.27 & - & $7.26 / 7.30$ & - & 7.17 & - & 7.27/7.32 \\
\hline $\mathrm{CO}$ & 169.16 & - & 168.92 & - & 169.12 & - & 168.75 & - \\
\hline \multicolumn{9}{|l|}{ Thr ${ }^{9}$} \\
\hline $\mathrm{NH}$ & - & 7.33 & - & 7.63 & - & 7.12 & - & 7.63 \\
\hline $\mathrm{C} \alpha \mathrm{H}$ & 55.61 & 4.49 & 55.25 & 4.57 & 55.83 & 4.46 & 55.56 & 4.56 \\
\hline $\mathrm{C} \beta \mathrm{H}$ & 66.23 & 3.93 & 66.54 & 3.98 & 66.43 & 3.90 & 66.50 & 3.97 \\
\hline $\mathrm{OH}$ & - & 4.94 & - & - & - & 4.89 & - & - \\
\hline $\mathrm{C} \gamma \mathrm{H}_{3}$ & 18.87 & 1.05 & 18.64 & 1.05 & $18.85^{*}$ & 1.03 & 18.59 & 1.05 \\
\hline $\mathrm{CO}$ & 168.58 & - & 168.87 * & - & 168.70 * & - & 169.04 * & - \\
\hline \multicolumn{9}{|c|}{ Pro $^{10} / \mathrm{Hyp}^{10}$} \\
\hline $\mathrm{C} \alpha \mathrm{H}$ & 59.60 & 4.33 & 59.90 & 4.37 & 58.62 & 4.43 & 58.87 & 4.44 \\
\hline $\mathrm{C} \beta \mathrm{H}_{2}$ & 29.08 & $1.82 / 2.04$ & 28.77 & $1.83 / 2.03$ & 37.73 & $1.84 / 2.01$ & 37.45 & $1.89 / 2.05$ \\
\hline $\mathrm{C} \gamma \mathrm{H}_{2}$ & 24.00 & $1.80 / 1.90$ & 24.16 & $1.83 / 1.90$ & 68.50 & 4.32 & 68.48 & 4.31 \\
\hline $\mathrm{OH}$ & & & & & & 5.08 & & - \\
\hline $\mathrm{C} \mathrm{H}_{2}$ & 47.16 & 3.68 & 47.49 & $3.64 / 3.75$ & 55.48 & $3.58 / 3.72$ & 55.60 & $3.60 / 3.76$ \\
\hline $\mathrm{CO}$ & 171.21 & - & 171.42 & - & $171.47^{* *}$ & - & 171.33 & - \\
\hline \multicolumn{9}{|l|}{ Leu $^{11}$} \\
\hline $\mathrm{NH}$ & - & 7.89 & - & 7.77 & - & 7.86 & - & 7.84 \\
\hline $\mathrm{C} \alpha \mathrm{H}$ & 51.36 & 4.31 & 51.44 & 4.30 & 51.31 & 4.35 & 51.36 & 4.29 \\
\hline $\mathrm{C} \beta \mathrm{H}_{2}$ & 40.82 & 1.47 & 40.44 & 1.47 & 41.24 & 1.47 & 40.51 & 1.46 \\
\hline $\mathrm{C} \gamma \mathrm{H}$ & 24.06 & 1.53 & 24.09 & 1.58 & 24.12 & 1.52 & 24.06 & 1.58 \\
\hline $\mathrm{C} \mathrm{H}_{3}$ & 22.71 & 0.87 & 22.96 & 0.86 & 22.75 & 0.86 & 22.83 & 0.86 \\
\hline $\mathrm{Cd}^{\prime} \mathrm{H}_{3}$ & 21.76 & 0.82 & 21.42 & 0.84 & 21.72 & 0.80 & 21.43 & 0.83 \\
\hline $\mathrm{CO}$ & 171.67 & - & 171.83 & - & $171.41^{* *}$ & - & 171.33 & - \\
\hline \multicolumn{9}{|l|}{ Thr $^{12}$} \\
\hline $\mathrm{NH}$ & - & 7.74 & - & 7.57 & - & 7.68 & - & 7.59 \\
\hline $\mathrm{C} \alpha \mathrm{H}$ & 57.85 & 4.11 & 58.13 & 4.10 & 58.17 & 4.10 & 58.12 & 4.10 \\
\hline $\mathrm{C} \beta \mathrm{H}$ & 66.19 & 4.00 & 66.52 & 3.97 & 66.35 & 3.97 & 66.50 & 3.97 \\
\hline $\mathrm{OH}$ & - & 4.78 & - & - & - & 4.80 & - & - \\
\hline $\mathrm{C} \gamma \mathrm{H}_{3}$ & 19.46 & 0.99 & 19.55 & 0.99 & 19.48 & 0.99 & 19.45 & 1.00 \\
\hline $\mathrm{CO}$ & 168.67 & - & $168.87^{*}$ & - & $168.67^{*}$ & - & $168.99 *$ & - \\
\hline
\end{tabular}

*,** $\mathrm{Thr}^{9}$ and $\mathrm{Thr}^{12}$ Chemical shifts may be interchanged.

Sequence-specific assignments were determined from the HMBC correlations (Figure S8) between carbonyl carbons (residue i) and $\mathrm{NH}$ or $\mathrm{NCH}_{3}$ protons (residue i+1). These data suggested the presence of two fragments consisting of Ala-Hle-Gln-N-MeIle-HAsn-Thr (fragment 1) and 
Pro-Leu-Thr- $\beta$-Ade-Val-Hle (fragment 2 ). These two partial sequences were confirmed by ROESY correlations between $\mathrm{H} \alpha$ or $\mathrm{H} \beta$ (residue i) and $\mathrm{NH}$ or $\mathrm{NCH}_{3}$ (residue i+1). Fragments 1 and 2 were assembled by two inter-residue ROESY correlations between $\mathrm{H} \alpha\left({ }_{\mathrm{H}} 4.57\right)$ and $\mathrm{H} \beta$ (ठн3.98) of Thr ${ }^{9}$ and $\mathrm{H \delta}(\delta \mathrm{H} 3.64 / 3.75)$ of $\mathrm{Pro}^{10}$, establishing the complete sequence as Ala-Hle-Gln- $N$-MeIle-HAsn-Thr-Pro-Leu-Thr- $\beta$-Ade-Val-Hle (Figure 5). MS/MS data for 11 were consistent with the proposed amino acid sequence with the y ions at $m / z 1213.50$ (y10), 1085.58 (y9), 828.42 (y7), and 727.42 (y6) and the b ions at $m / z 1266.75$ (b11), 1167.58 (b10), and 456.25 (b4).
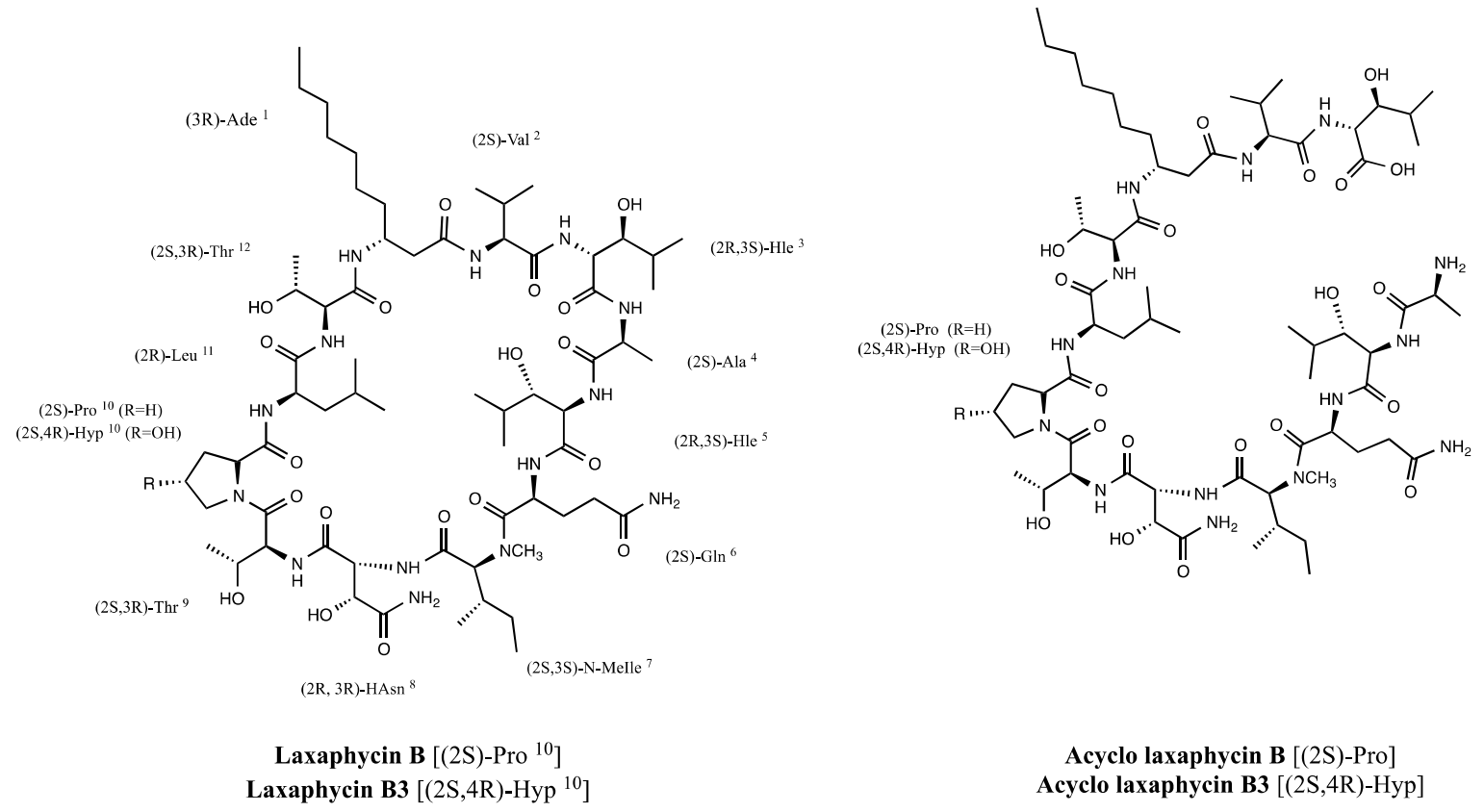

Figure 5. Structures of laxaphycins B (9) and B3 (10), and acyclolaxaphycins B (11) and B3 (12).

\subsubsection{Acyclolaxaphycin B3 (12): Structure Elucidation}

Preliminary spectral data examination, including ${ }^{1} \mathrm{H}$ and ${ }^{13} \mathrm{C}-\mathrm{NMR}$ spectroscopy, showed that the new compound was an analog of laxaB3 (10) and acyclolaxaB (11) (Figure S9). HRESIMS analysis yielded a $[\mathrm{M}+\mathrm{H}]^{+}$pseudomolecular ion at $m / z 1429.8482$ for a molecular formula of $\mathrm{C}_{65} \mathrm{H}_{116} \mathrm{~N}_{14} \mathrm{O}_{21}$. In comparison to laxaB3 $\left(\mathrm{C}_{65} \mathrm{H}_{114} \mathrm{~N}_{14} \mathrm{O}_{20}\right)$, this corresponds to a gain of $\mathrm{H}_{2} \mathrm{O}$ and to acyclolaxaB gain of an oxygen atom.

A similar pattern of fragmentation for both compounds $\mathbf{1 1}$ and $\mathbf{1 2}$ was observed. Comparison of MS/MS spectra showed the same b4 fragment at $m / z 456.25$, the b11 $(m / z 1282.76), y 6(m / z 743.49), y 7$ $(\mathrm{m} / \mathrm{z}$ 844.54), $\mathrm{y} 9(\mathrm{~m} / \mathrm{z}$ 1101.68), and $\mathrm{y} 10(\mathrm{~m} / \mathrm{z} 1229.72)$ ions being shifted to a higher mass by $16 \mathrm{amu}$. In the HRESIMS/MS spectra of 12, b9 $\left(\mathrm{m} / \mathrm{z}\right.$ 1014.55060, $\mathrm{C}_{44} \mathrm{H}_{76} \mathrm{~N}_{11} \mathrm{O}_{16}{ }^{+}, \Delta$ obs/calc $\left.=0.004\right)$ and b11 $(\mathrm{m} / \mathrm{z}$ $\left.1282.76672, \mathrm{C}_{59} \mathrm{H}_{104} \mathrm{~N}_{13} \mathrm{O}_{18}{ }^{+}, \Delta \mathrm{obs} / \mathrm{calc}=0.005\right)$ fragments were observed. The y6 and b9 fragments in compound 12 shifted by 16 amu compared to 11, suggesting that the variable residue could be in position 10,11, or 12, corresponding to the Pro, Leu, or Thr residues, respectively.

The NMR spectral analysis (Figures S9-S14) of acyclolaxaB3 showed remarkable similarities with acyclolaxaB (11) and established the variable residue as Pro/Hyp (Figure 5). The significant difference was the presence of an additional hydroxyl group on proline $(\mathrm{H} \gamma$ at $4.31 \mathrm{ppm} v$ s. two $\mathrm{H} \gamma$ at 1.83 and $1.90 \mathrm{ppm}$ for compound 11; $\mathrm{C} \gamma$ at $68.48 \mathrm{ppm} v \mathrm{~s} .24 .16 \mathrm{ppm}$ for compound 11; $\mathrm{C} \beta$ and $\mathrm{C} \delta$ were also deblinded by the presence of the hydroxyl function ( $\Delta \delta 8.68$ and $8.11 \mathrm{ppm}$, respectively)). HMBC and ROESY correlations established the complete sequence as Ala-Hle-Gln- $N$-Melle-HAsn-Thr-Hyp-Leu-Thr- $\beta$-Ade-Val-Hle for compound 12, and the gross structure of the new compound, acyclolaxaphycin B3, differed from acyclolaxaphycin B with a replacement of Pro by Hyp. 


\subsubsection{Acyclolaxaphycins B (11) and B3 (12): Clues to Their Biosynthesis}

Acyclolaxaphycins B (11) and B3 (12) are acyclic analogs of laxaphycins B (9) and B3 (10), respectively. They are two novel acyclic structural variants of a core structure (B-type laxaphycins) composed of about 10 cyanobacterial $\beta$-amino fatty acid cyclic dodecapeptides, laxaphycins B, B2, B3, and D, lyngbyacyclamides A-B, lobocyclamides B-C, and trichormamides B-C (Figure 1) with conserved amino acid residues. The chemical structure of all these compounds were similar, maintaining a 12 -membered ring and sharing the (3R)- $\beta$-amino fatty acid ( $\beta$-Aoc or $\beta$-Ade), (2R,3S)-Hle, (2S)-Gln, (2S)-N-MeIle, (2S,3R)-Thr, and (2S,3R)-Thr in the positions 1, 3, 6, 7, 9, and 12. In positions $2,4,5,8,10$, and 11 , the amino acid residues can vary, but their configuration at each position is strongly conserved.

An important subset of the $\beta$-hydroxylation of various amino acid residues observed for non-ribosomal synthesized peptides is catalyzed by cytochrome P450 monoxygenases [32-34]. The same biological machinery is certainly responsible for the $\beta$-hydroxylation of leucine and asparagine in laxaphycins and as this reaction is stereospecific, the stereochemistry of hydroxy-leucines, in position 3 and 5, and hydroxy-asparagine, in position 8 , must be conserved.

Furthermore, both new peptides showed very similar NMR chemical shifts to laxaphycins B and B3 for the peptidic chain as well as for the side chains, indicating a conservation of the stereochemistry between cyclic and acyclic analogs. An indication of this homology could be seen in the comparison of ${ }^{1} \mathrm{H}$ and ${ }^{13} \mathrm{C}$ resonances of acyclolaxaphycins $\mathrm{B}$ and $\mathrm{B} 3$ with the parent compounds laxaphycins B and B3 $(\mathrm{H} \alpha, \mathrm{H} \beta, \mathrm{C} \alpha$, and $\mathrm{C} \beta$ acyclolaxaphycins $\mathrm{B}$ and $\mathrm{B} 3$ resonances subtracted from the equivalent ones of laxaphycin $\mathrm{B}$ and $\mathrm{B} 3$, respectively). With the exception of the structurally modified parts of the molecule, residues 4 and 5 on the $\mathrm{NH}$ terminal side and residues 2 and 3 on the $\mathrm{COOH}$ terminal side, the maximum difference $(\Delta \delta)$ observed was less than $0.1 \mathrm{ppm}$ in ${ }^{1} \mathrm{H}$ and $0.8 \mathrm{ppm}$ in ${ }^{13} \mathrm{C}$.

Therefore the complete structure of the two new compounds can be reasonably proposed as: (2S)-Ala-(2R,3S)-HLe-(2S)-Gln-(2S,3S)-N-MeIle-(2R,3R)-HAsn-(2S,3R)-Thr-(2S)-Pro-(2R)Leu-(2S,3R)-Thr-(3R)- $\beta$-Ade-(2S)-Val-(2R,3S)-HLe for acyclolaxaphycin $B \quad(11)$ and (2S)-Ala-(2R,3S)-HLe-(2S)-Gln-(2S,3S)-N-Melle-(2R,3R)-HAsn-(2S,3R)-Thr-(2S,4R)-4-Hyp -(2R)-Leu-(2S,3R)-Thr-(3R)- $\beta$-Ade-(2S)-Val-(2R,3S)-HLe for acyclolaxaphycin B3 (12).

A putative operon encoding the biosynthetic pathway for $\beta$-amino fatty acid lipopeptides, the puwainaphycins, was identified in the cyanobacterium Cylindrospermum alatosporum; the peptide biosynthesis process is initiated by the activation of a fatty acid residue via fatty acyl-AMP ligase (FAAL) and continued by a multidomain non-ribosomal peptide synthase/polyketide synthetase [35]. The last module incorporates a thioesterase domain in its terminal part that cleaves the finished puwainaphycin chain from the peptidyl carrier protein, thus promoting its cyclization between the $\mathrm{NH}_{2}$ of $\beta$-amino fatty acid and the $\mathrm{COOH}$ of a proline residue. The characterization of the two novel acyclic laxaphycin variants $\mathbf{1 1}$ and $\mathbf{1 2}$ with alanine as $\mathrm{NH}$ terminal and Hle as $\mathrm{COOH}$ terminal seemed to indicate that in the case of B-type laxaphycins, the biosynthesis process starts with NRPS modules instead of FAAL and acyl carrier protein (ACP) ligase, with the ring closure being performed through a cyclization reaction between the amino group of the alanine residue and the carbonyl of the hydroxyleucine residue. However, one cannot exclude that acyclolaxaphycins B and B3 are enzymatic degradation products formed during cyanobacteria blooms. Enzymatic degradation is often used in resistance mechanisms in the microbial world or in competitive interspecific interactions. Enzymes that degrade or modify natural products provide protection by decreasing toxicity or by regulating the signaling functions of metabolites. Recently, Hoefler et al. have observed hydrolysis of cyclic lipopeptides surfactins by bacterial competition using imaging mass spectrometry [36]. However, the ring opening of the cyclic surfactins occured at the ester functional group, which is not the case in laxaphycin peptides. 


\section{Experimental Section}

\subsection{Sampling Sites}

The cyanobacterium $A$. cf torulosa was collected by SCUBA diving at a depth of 1-3 $\mathrm{m}$ in the Pacific Ocean, Moorea, French Polynesia. The cyanobacterium sample was sealed underwater in a bag with seawater and then freeze-dried.

\subsection{Isolation Procedure}

The freeze-dried sample of cynaobacterium A. cf torulosa (600 g) was extracted at room temperature three times with a mixture of $\mathrm{MeOH}-\mathrm{CH}_{2} \mathrm{Cl}_{2}(1: 1)$ and ultrasound. The combined extracts were evaporated under reduced pressure to give a greenish organic extract $(38 \mathrm{~g})$. The extract was subjected to flash RP18 silica gel column eluted with $\mathrm{H}_{2} \mathrm{O}(\mathrm{A}), \mathrm{H}_{2} \mathrm{O}-\mathrm{CH}_{3} \mathrm{CN}(2: 8)$ (B), $\mathrm{MeOH}(\mathrm{C})$, and $\mathrm{MeOH}-\mathrm{CH}_{2} \mathrm{Cl}_{2}$ (8:2) (D) to afford four fractions (A, $\mathrm{B}, \mathrm{C}$, and D). Then, fraction $\mathrm{B}(2 \mathrm{~g})$ was subjected to flash RP18 silica gel column eluted with a solvent gradient of $\mathrm{H}_{2} \mathrm{O}-\mathrm{CH}_{3} \mathrm{CN}$ to produce 12 fractions. Fraction 4 was subjected to HPLC purification (UP-50 DB.25M Uptisphere $5 \mu$ ) using $62 \% \mathrm{H}_{2} \mathrm{O}-\mathrm{CH}_{3} \mathrm{CN}$ at a flow rate of $3 \mathrm{~mL} / \mathrm{min}$ to give acyclolaxaphycin $\mathrm{B} 3(3 \mathrm{mg}, \mathrm{tr}=28.8 \mathrm{~min}$ ) and acyclolaxaphycin $\mathrm{B}(2 \mathrm{mg}, \mathrm{tr}=31.2 \mathrm{~min})$.

\subsection{Mass and NMR Spectroscopies}

High-resolution ESI mass spectra were obtained using a Thermo Scientific LTQ Orbitrap mass spectrometer using electrospray ionization in positive mode. 1D-NMR and 2D-NMR experiments of synthetic compounds 1, 2, 8, and 9 were acquired on a JEOL EX 400 spectrometer equipped with a $\mathrm{NM}-40$ dual ${ }^{1} \mathrm{H},{ }^{13} \mathrm{C}$ probe, whereas those of natural compounds $9, \mathbf{1 0}, \mathbf{1 1}$, and 12 were acquired on a Brucker Avance 500 spectrometer equipped with a cryogenic probe $(5 \mathrm{~mm})$, all compounds in DMSO- $d_{6}(500 \mu \mathrm{L})$ at $303 \mathrm{~K}$. All chemical shifts were calibrated on the residual solvent peak (DMSO- $d_{6}, 2.50 \mathrm{ppm}\left({ }^{1} \mathrm{H}\right)$ and $39.5 \mathrm{ppm}\left({ }^{13} \mathrm{C}\right)$ ). The chemical shifts, reported in delta $(\delta)$ units, and in parts per million (ppm) are referenced relatively to TMS.

\subsection{Solid Phase Peptide Synthesis}

Fmoc-protected amino acids, coupling reagents and Rink Amide resin were purchased from Novabiochem (Fontenay-sous-Bois, France) or Iris Biotech (Marktredwitz, Germany). Fmoc-(alloD)Ile-OH and Boc-(L)Lys(Fmoc)-OH were bought from Iris Biotech (Marktredwitz, Germany). DMF for peptide synthesis, and other chemicals were purchased from Aldrich (Saint-Quentin Fallavier, France). Automated solid phase Fmoc-synthesis was performed on a Liberty One synthesizer by CEM (Saclay, France).

Synthesis protocol for automated solid phase peptide synthesis: Automated solid-phase peptide synthesis was performed on a $0.1 \mathrm{mmol}$ scale. $278 \mathrm{mg}$ of Rink amide MBHA LL resin at a $0.36 \mathrm{mmol} / \mathrm{g}$ substitution level was pre-swollen for $60 \mathrm{~min}$ in DMF and the solvent was drained. Fmoc-removal was achieved with a $20 \%$ piperidine solution in DMF, initial deprotection $30 \mathrm{~s}, 40 \mathrm{~W}$, $75^{\circ} \mathrm{C}$, second step $180 \mathrm{~s}, 40 \mathrm{~W}, 70^{\circ} \mathrm{C}$. After washing $(3 \times 7 \mathrm{~mL}$ DMF), $2.5 \mathrm{~mL}$ of a $0.2 \mathrm{M}$ solution of the amino acid in DMF (5 eq relative to resin loading) was added. After addition of a $2 \mathrm{M}$ solution of DIPEA in DMF $(0.5 \mathrm{~mL}, 10 \mathrm{eq})$ and a $0.45 \mathrm{M}$ solution of HATU in DMF $(1 \mathrm{~mL}, 4.5 \mathrm{eq})$, the reaction solution was irradiated at $25 \mathrm{~W}$ for $5 \mathrm{~min}$ reaching a final temperature of $70{ }^{\circ} \mathrm{C}$. All amino acids were coupled using these conditions except Fmoc-Gln(Trt)-OH for which a triple coupling was performed with a prolonged reaction time of $20 \mathrm{~min}$. After full elongation of the peptide, the linear protected peptide linked to the resin was transferred into a batch reactor and the allyl protecting group was cleaved using $\mathrm{Pd}\left(\mathrm{P}\left(\mathrm{Ph}_{3}\right)\right)_{4}(\mathrm{~m}=0.35 \mathrm{~g}, 0.3 \mathrm{mmol}, 3 \mathrm{eq})$ with a solution of $\mathrm{CHCl}_{3} / \mathrm{AcOH} \mathrm{NMM}$ : 3.7/0.2/01 for $4 \mathrm{~h}$ at room temperature. After washing the resin using a solution of $0.5 \%$ diethyldithiocarbamate in DMF $(3 \times 10 \mathrm{~mL})$ and DMF $(3 \times 10 \mathrm{~mL})$ and lastly Fmoc removal, the cyclisation was performed with diisopropylcarbodiimide (DIC) and Oxyma, $1 \mathrm{~mL}, \mathrm{C}=0.5 \mathrm{M}, 70^{\circ} \mathrm{C} 3$ $\times 20 \mathrm{~min}$, then $120 \mathrm{~s}$ at $20^{\circ} \mathrm{C}$ between each cycle, followed by a final wash with DMF $(3 \times 7 \mathrm{~mL})$. A 
Kaiser test was carried out in order to check reaction completion. Finally, the resin was washed with DCM $(3 \times 10 \mathrm{~mL})$, transferred to a flask, and the cleavage cocktail (TFA, $\left.\mathrm{H}_{2} \mathrm{O}, \mathrm{TIS} 95 / 2.5 / 2.5\right)$ added. The resin was shaken for $3 \mathrm{~h}$. The cleaving solution was collected and the resin washed with TFA $(2 \times$ $3 \mathrm{~mL}$ ). The combined fractions were concentrated in vacuum. The crude peptide was precipitated in cold $\mathrm{Et}_{2} \mathrm{O}$ and finally centrifuged. The precipitate was washed with cold ether, extracted with water, and freeze-dried to yield the crude peptide.

Analytical HPLC of peptides: The HPLC analysis was run on a Waters (Guyancourt, France) 2695 HPLC system fitted with an ELS detector 2424 and a PDA 2998 using a Phenomenex Luna $3 \mu M$ C-8 column $(150 \times 3 \mathrm{~mm})$. Eluents were water with $0.1 \%$ formic acid (buffer A) and acetonitrile with $0.1 \%$ formic acid (buffer B). Standard conditions comprised a flow rate of $0.4 \mathrm{~mL} / \mathrm{min}$ eluting with $40 \%$ B to $100 \%$ B in 35 min. Standard conditions were applied to all HPLC analyses unless stated otherwise.

Semi-preparative HPLC purification of peptide crudes: A semi-preparative purification of cyclic peptides was performed using a Waters 1525 chromatography system fitted with a Waters 2487 tunable absorbance detector with detection at $214 \mathrm{~nm}$ (Guyancourt, France). Purification was performed by eluting solvents A (water) and B (acetonitrile) on a UP50DB C-18 column $(250 \times 10 \mathrm{~mm})$ at $3 \mathrm{~mL} / \mathrm{min}$.

LC-MS: LC-MS analyses were carried out using a Thermo Fisher Scientific LC-MS device, Accela HPLC coupled to a LCQ Fleet equipped with an electrospray ionisation source and a 3D ion-trap analyzer (Villebon-sur-Yvette, France). The analysis was performed with a Phenomenex Kinetex C-18 column $(100 \times 300 \mathrm{~mm})$ using gradient mixture of water with $0.1 \%$ formic acid (buffer A) and acetonitrile with $0.1 \%$ formic acid (buffer B). Standard conditions were a flow rate of $0.5 \mathrm{~mL} / \mathrm{min}$ eluting with $20 \%$ B to $100 \%$ B in 15 min. Standard conditions were applied to all HPLC-MS analysis unless otherwise stated.

Fmoc-NMeIle-OH (1.10 g, $3.0 \mathrm{mmol})$ was dissolved in DMF $(7 \mathrm{~mL})$ and cesium carbonate $(0.98 \mathrm{~g}$, $3.0 \mathrm{mmol})$ added. The mixture was stirred for $2 \mathrm{~h}$. Allyl bromide $(2.54 \mathrm{~g}, 1.80 \mathrm{~mL}, 21.0 \mathrm{mmol})$ was added to the mixture and stirring continued for $1 \mathrm{~h}$ resulting in a milky solution. The mixture was diluted to $20 \mathrm{~mL}$ with water and acidified with $1 \mathrm{M} \mathrm{HCl}$. The aqueous layer was extracted with dichloromethane $(25 \mathrm{~mL}, 3 \times 25 \mathrm{~mL})$. The organic layer was washed with brine $(15 \mathrm{~mL})$, dried over $\mathrm{MgSO}_{4}$, and filtered, and the solvent was removed under reduce pressure to give $4 \mathbf{a}$ (Figure 6) as a colorless oil (0.92, 76\%). ${ }^{1} \mathrm{H}-\mathrm{NMR}\left(\mathrm{CDCl}_{3}\right)$ : 7.76 (d, 2H, J = $\left.7.5 \mathrm{~Hz}\right) ; 7.59$ (d, 2He, J = 8.2 Hz); 7.39 (t, $2 \mathrm{H}_{\mathrm{c}}$, $J=7.8 \mathrm{~Hz}) ; 7.28(\mathrm{t}, 2 \mathrm{Hd}, J=7.5 \mathrm{~Hz}) ; 5.89(\mathrm{~m}, 1 \mathrm{Hn}) ; 5.32\left(\mathrm{dt}, 2 \mathrm{Hm}_{\mathrm{m}} J=17.4 \mathrm{~Hz}, J=10.4 \mathrm{~Hz}\right) ; 4.61\left(\mathrm{~m}, 2 \mathrm{H}_{\mathrm{l}}\right)$; $4.51(\mathrm{~m}, 1 \mathrm{H}) ; 4.25(\mathrm{~m}, 1 \mathrm{H}) ; 2.90\left(\mathrm{~s}, 3 \mathrm{H}_{\mathrm{j}}\right) ; 2.00\left(\mathrm{~m}, 1 \mathrm{H}_{\mathrm{o}}\right) ; 1.38\left(\mathrm{~m}, 2 \mathrm{H}_{\mathrm{r}}\right) ; 0.90\left(\mathrm{~d}, 3 \mathrm{H}_{\mathrm{q}}, J=7.3 \mathrm{~Hz}\right) ; 0.85(\mathrm{t}$, $\left.3 \mathrm{H}_{\mathrm{s}}, \mathrm{J}=6.6 \mathrm{~Hz}\right) .{ }^{13} \mathrm{C}-\mathrm{NMR}\left(\mathrm{CDCl}_{3}\right): 171.6\left(\mathrm{Cl}_{\mathrm{l}}=\mathrm{O}\right) ; 156.4\left(\mathrm{C}_{\mathrm{i}}=\mathrm{O}\right) ; 144.1\left(\mathrm{C}_{\mathrm{f}}\right) ; 141.4\left(\mathrm{C}_{\mathrm{a}}\right) ; 131.8\left(\mathrm{C}_{\mathrm{nH}}\right) ; 128.4$ $(\mathrm{CeH}) 127.7(\mathrm{CbH}) ; 125.1\left(\mathrm{CdH}_{\mathrm{dH}}\right) 120.0\left(\mathrm{C}_{\mathrm{cH}}\right) ; 118.5\left(\mathrm{CoH}_{\mathrm{o}}\right) ; 67.7\left(\mathrm{C}_{\mathrm{kH}}\right) ; 65.3\left(\mathrm{C}_{\mathrm{hH}}\right) ; 62.5\left(\mathrm{C}_{\mathrm{mH}}\right) ; 47.4$ $\left(\mathrm{C}_{\mathrm{g}} \mathrm{H}\right) ; 33.6\left(\mathrm{C}_{\mathrm{j}} \mathrm{H} 3\right) ; 30.1\left(\mathrm{C}_{\mathrm{p}} \mathrm{H}\right) ; 25.0\left(\mathrm{C}_{\mathrm{rH}}\right) ; 15.8\left(\mathrm{C}_{\mathrm{q}} \mathrm{H}_{3}\right) ; 11.0\left(\mathrm{C}_{\mathrm{s}} \mathrm{H}_{3}\right)$.

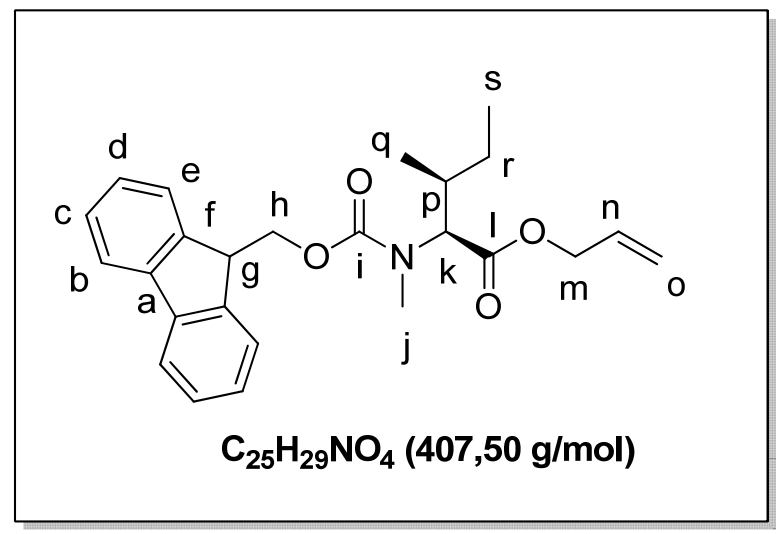

Figure 6. (2S,3S)-allyl 2-(((9H-fluoren-9-yl)methoxy)carbonyl)(methyl)amino)-3-methylpentanoate (4a). 
A solution of compound $4 \mathrm{a}(1.10 \mathrm{~g}, 3.0 \mathrm{mmol})$ in DMF $(5 \mathrm{~mL})$ was treated with piperidine (1 $\mathrm{mL}$ ). The mixture was stirred for $1 \mathrm{~h}$. The mixture was diluted to $20 \mathrm{~mL}$ and the aqueous phase was extracted with cHex/AcOEt, 50/50 $(3 \times 30 \mathrm{~mL})$. The organic layer was washed with brine $(15 \mathrm{~mL})$, dried over $\mathrm{MgSO}_{4}$, and filtered, and the solvent was removed under reduced pressure. The crude product was purified by flash chromatography on silica gel (eluent: cHex/AcOEt 6/4) to yield $4 \mathbf{b}$ (Figure 7) as a colorless oil $(0.29 \mathrm{~g}, 70 \%)$. ${ }^{1} \mathrm{H}-\mathrm{NMR}\left(\mathrm{CDCl}_{3}\right): 5.95\left(\mathrm{~m}, 1 \mathrm{H}_{\mathrm{f}}\right) ; 5.32\left(\mathrm{dd}, 2 \mathrm{H}_{\mathrm{g}}, J=22.5 \mathrm{~Hz}, J=\right.$ $11.3 \mathrm{~Hz}) ; 4.65\left(\mathrm{~m}, 2 \mathrm{H}_{\mathrm{e}}\right) ; 3.25\left(\mathrm{~d}, 1 \mathrm{H}_{\mathrm{c}}, J=5.3 \mathrm{~Hz}\right) ; 2.50\left(3 \mathrm{~s}, 1 \mathrm{H}_{\mathrm{a}}\right) ; 1.92\left(\mathrm{~m}, 1 \mathrm{Hh}_{\mathrm{h}}\right) ; 1.54\left(\mathrm{~m}, 2 \mathrm{H}_{\mathrm{j}}\right) ; 0.92\left(\mathrm{~d}, 3 \mathrm{H}_{\mathrm{i}}\right.$, $J=6.8 \mathrm{~Hz}) ; 0.80\left(\mathrm{t}, 3 \mathrm{H}_{\mathrm{k}}, J=7.3 \mathrm{~Hz}\right) .{ }^{13} \mathrm{C}-\mathrm{NMR}\left(\mathrm{CDCl}_{3}\right): 170.6\left(\mathrm{C}_{\mathrm{d}}=\mathrm{O}\right) ; 131.5(\mathrm{CfH}) ; 119.6\left(\mathrm{C}_{\mathrm{g}} \mathrm{H}_{2}\right) ; 66.9$ $\left(\mathrm{C}_{\mathrm{eH}}\right) ; 66.1\left(\mathrm{C}_{\mathrm{cH}}\right) ; 37.3\left(\mathrm{C}_{\mathrm{hH}}\right) ; 34.2\left(\mathrm{C}_{\mathrm{aH}}\right) ; 26.3\left(\mathrm{C}_{\mathrm{j}} \mathrm{H}_{2}\right) ; 15.3\left(\mathrm{C}_{\mathrm{iH}}\right) ; 11.7\left(\mathrm{C}_{\mathrm{kH}}\right)$.

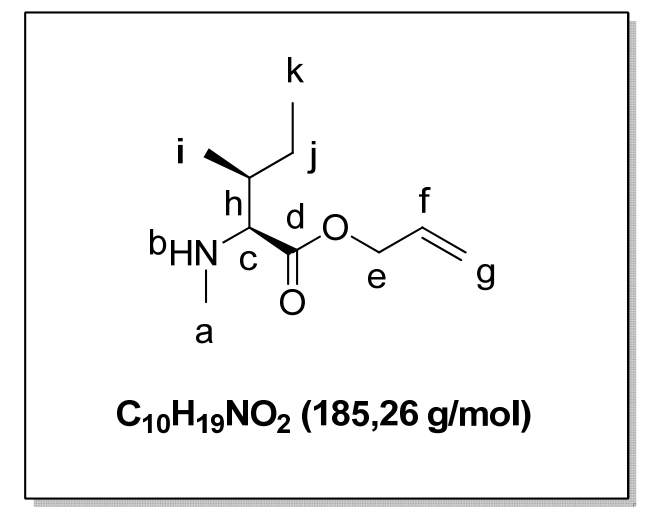

Figure 7. (2S,3S)-allyl 3-methyl-2-(methylamino)pentanoate (4b).

A solution of Fmoc-Glu(OtBu)-OH $(0.56 \mathrm{~g}, 1.30 \mathrm{mmol})$ in DMF $(6 \mathrm{~mL})$ was treated with DIEA $(0.23 \mathrm{~mL}, 1.30 \mathrm{mmol})$. The mixture was cooled at $0{ }^{\circ} \mathrm{C}$ and COMU $(0.56,1.30 \mathrm{mmol})$ was added. After $5 \mathrm{~min}$, solutions of compound $4 \mathbf{b}(0.24 \mathrm{~g}, 1.30 \mathrm{mmol})$ in DMF $(2 \mathrm{~mL})$ and DIEA $(0.23 \mathrm{~mL}, 1.30 \mathrm{mmol})$ were added successively at $0{ }^{\circ} \mathrm{C}$. The reaction mixture was allowed to warm to room temperature and stirred for $48 \mathrm{~h}$. The mixture was extracted with cHex/EtOAc, 50/50 $(3 \times 10 \mathrm{~mL})$. The organic layer was washed successively with a solution of $\mathrm{HCl} 1 \mathrm{M}(10 \mathrm{~mL})$, saturated aqueous $\mathrm{NaHCO}_{3}(10$ $\mathrm{mL})$, and brine $(10 \mathrm{~mL})$, and dried over $\mathrm{MgSO}_{4}$. The solvent was removed under reduced pressure. The crude product was purified by chromatography on silica gel using cHex/AcOEt (80/20) as eluent to yield compound 3a (Figure 8$)$ as a yellow oil $(0.50 \mathrm{~g}, 70 \%) .{ }^{1} \mathrm{H}-\mathrm{NMR}\left(\mathrm{CDCl}_{3}\right): 7.75(\mathrm{~d}, 2 \mathrm{Hb}, J=7.3$ $\mathrm{Hz}) ; 7.60\left(\mathrm{~d}, 2 \mathrm{H}_{\mathrm{e}}, J=6.2 \mathrm{~Hz}\right) ; 7.40(\mathrm{t}, 2 \mathrm{Hc}, J=7.3 \mathrm{~Hz}) ; 7.22(\mathrm{~m}, 2 \mathrm{Hd}) ; 5.89\left(\mathrm{~m}, \mathrm{NH}_{\mathrm{j}}\right) ; 5.65\left(\mathrm{~m}, 1 \mathrm{H}_{\mathrm{v}}\right) ; 5.32$ $\left(\mathrm{dd}, 2 \mathrm{H}_{\mathrm{w}}, J=15.6 \mathrm{~Hz}, J=10.2 \mathrm{~Hz}\right) ; 4.97\left(\mathrm{~d}, 1 \mathrm{H}_{\mathrm{k}}, J=10.2 \mathrm{~Hz}\right) ; 4.75\left(\mathrm{~m}, 1 \mathrm{H}_{\mathrm{s}}\right) ; 4.60\left(\mathrm{~m}, 2 \mathrm{H}_{\mathrm{u}}\right) ; 4.36\left(\mathrm{~d}, 2 \mathrm{Hh}_{\mathrm{h}}\right.$ $J=7.1 \mathrm{~Hz}) ; 4.21\left(\mathrm{t}, 1 \mathrm{H}_{\mathrm{g}}, J=6.8 \mathrm{~Hz}\right) ; 3.10\left(\mathrm{~s}, 3 \mathrm{H}_{\mathrm{r}}\right) ; 2.34(\mathrm{~m}, 2 \mathrm{Hm}) ; 2.03\left(\mathrm{~m}, 2 \mathrm{H}_{\mathrm{l}}\right) ; 1.56\left(\mathrm{~m}, 1 \mathrm{H}_{\mathrm{x}}\right) ; 1.45(\mathrm{~s}$, $\left.9 \mathrm{H}_{\mathrm{p}}\right) ; 1.29\left(\mathrm{~m}, 2 \mathrm{H}_{\mathrm{z}}\right) ; 0.98\left(\mathrm{~d}, 3 \mathrm{H}_{\mathrm{y}}, J=6.6 \mathrm{~Hz}\right) ; 0.86\left(\mathrm{t}, 3 \mathrm{H}_{z^{\prime}}, J=7.3 \mathrm{~Hz}\right)$.

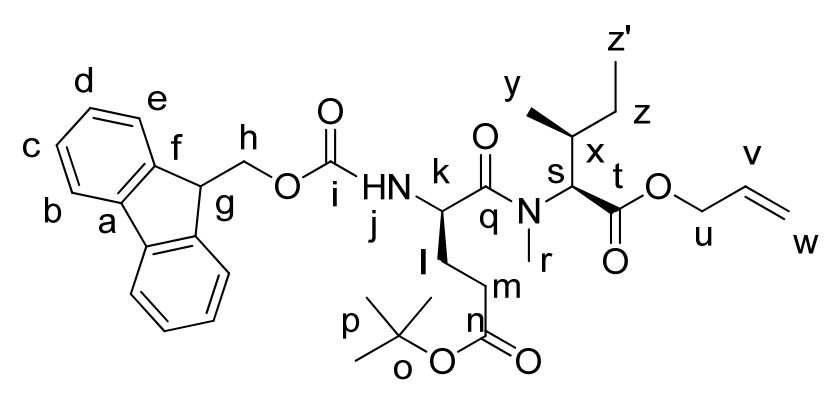

$\mathrm{C}_{34} \mathrm{H}_{44} \mathrm{~N}_{2} \mathrm{O}_{7}(592,72 \mathrm{~g} / \mathrm{mol})$

Figure 8. (R)-tert-butyl4-(((9H-fluoren-9-yl)methoxy)carbonyl)amino)-5-(((2S,3S)-1-(allyloxy)3-methyl-1-oxopentan-2-yl)(methyl)amino)-5-oxopentanoate (3a). 
A solution of compound 3a $(0.5 \mathrm{~g}, 0.90 \mathrm{mmol})$ in $\mathrm{CH}_{2} \mathrm{Cl}_{2}(4 \mathrm{~mL})$ was treated with TFA (4 mL). The mixture was stirred for $12 \mathrm{~h}$. The solvent was removed under reduced pressure and the crude product was purified by flash chromatography on silica gel (eluent: cHex/AcOEt 95/5) to yield $\mathbf{3 b}$ (Figure 9) as a white solid $(0.43 \mathrm{~g}, 96 \%) .{ }^{1} \mathrm{H}-\mathrm{NMR}\left(\mathrm{CDCl}_{3}\right): 7.75(\mathrm{~d}, 2 \mathrm{Hb}, J=7.3 \mathrm{~Hz}) ; 7.60(\mathrm{~d}, 2 \mathrm{He}, J=6.2$ $\mathrm{Hz}) ; 7.40\left(\mathrm{t}, 2 \mathrm{H}_{\mathrm{c}}, J=7.3 \mathrm{~Hz}\right) ; 7.22\left(\mathrm{~m}, 2 \mathrm{H}_{\mathrm{d}}\right) ; 5.89\left(\mathrm{~m}, \mathrm{NH}_{\mathrm{j}}\right) ; 5.32\left(\mathrm{dd}, 2 \mathrm{H}_{\mathrm{t}}, J=15.6 \mathrm{~Hz}, 10.2 \mathrm{~Hz}\right) ; 4.95(\mathrm{~d}$, $\left.2 \mathrm{H}_{\mathrm{k}}, J=7.2 \mathrm{~Hz}\right) ; 4.80\left(\mathrm{~m}, 1 \mathrm{H}_{\mathrm{u}}\right) ; 4.60\left(\mathrm{~d}, 2 \mathrm{H}_{\mathrm{r}}, J=5.9 \mathrm{~Hz}\right) ; 4.36(\mathrm{~m}, 2 \mathrm{Hh}) ; 4.20\left(\mathrm{t}, 1 \mathrm{H}_{\mathrm{g}}, J=7.0 \mathrm{~Hz}\right) ; 3.10(\mathrm{~s}$, $\left.3 \mathrm{H}_{\mathrm{p}}\right) ; 2.47\left(\mathrm{~m}, 2 \mathrm{Hm}_{\mathrm{m}}\right) ; 2.03\left(\mathrm{~m}, 2 \mathrm{H}_{\mathrm{l}}\right) ; 1.56\left(\mathrm{~m}, 1 \mathrm{H}_{\mathrm{v}}\right) ; 1.30\left(\mathrm{~m}, 2 \mathrm{H}_{\mathrm{x}}\right) ; 0.98\left(\mathrm{~d}, 3 \mathrm{H}_{\mathrm{w}}, J=6.6 \mathrm{~Hz}\right) ; 0.86\left(\mathrm{t}, 3 \mathrm{H}_{\mathrm{y}}, J=\right.$ $7.3 \mathrm{~Hz}) .(\mathrm{ESI}+) \mathrm{m} / z[\mathrm{M}+\mathrm{H}]^{+}$calcd for $\mathrm{C}_{30} \mathrm{H}_{37} \mathrm{~N}_{2} \mathrm{O}_{7} 536.6$, found 536.8 .

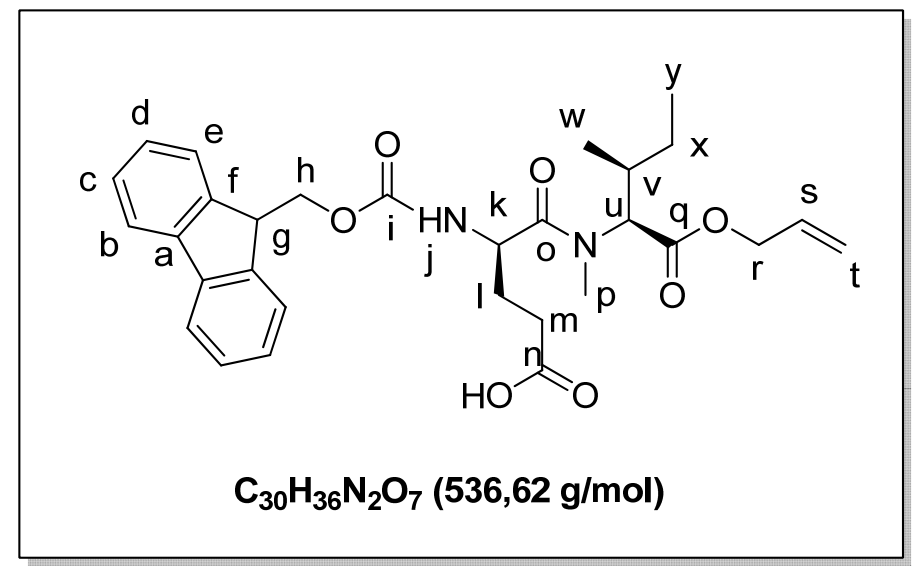

Figure 9 (R)-4-((((9H-fluoren-9-yl)methoxy)carbonyl)amino)-5-(((2S,3S)-1-(allyloxy)-3-methyl-1oxopentan-2-yl)(methyl)amino)-5-oxopentanoic acid (3b).

\section{Conclusions}

As shown in this work, the preliminary synthesis of the simplified analogs (1) and (2) of the targeted natural compound was a prerequisite for the synthesis of $\left((2 S, 3 S)-\mathrm{Hl}^{3}\right)$ laxaphycin $\mathrm{B}$, the diastereoisomer of the natural compound that was initially described [9]. This initial work resulted in the development of a total synthesis of laxaphycin B and lyngbyacyclamide [19].

This methodological approach is also important for future synthesis of laxaB-type peptides such as the two new linear lipopeptides acyclolaxaphins B and B3 $(11,12)$ isolated from the tropical marine cyanobacterium Anabaena cf. torulosa, the same species in which we have already isolated the related cyclic peptides laxaphins B and B3. The presence of these acyclic laxa B-type compounds together with the cyclized ones in the same extract has, to our knowledge, never been described. The search of other minor acyclic potential biosynthetic precursors will provide valuable information concerning the hybrid PKS/NRPS biosynthetic pathway in this exciting lipophilic cyclic dodecapeptide series. Furthermore, these acyclic peptides suggest another possible disconnection for the future preparation of new analogs of laxaphycin B at the HLe ${ }^{3} / \mathrm{Ala}^{4}$ junction. In this case we could expect that the linear peptide would benefit from a pre-organized structure thanks to its almost syndiotactic character [37,38]. Further work is needed to verify this assumption and to develop a synthesis based on the use of a BAL linker [39], which could enable other laxaphycin B type peptides to be synthesised.

Acknowledgments: We thank Prof. Olivier Thomas (ICN, Nice) for MS data acquisition and Prof. Christian Roumestand (CBS, Montpellier) for NMR measurements. This study was supported by two programs, SALSA (ANR-2010-BLAN-1533-02) and BQR, granted by the Agence Nationale de la Recherche (ANR) and Université de Perpignan Via Domitia, respectively. Chromatographic, spectroscopic, and structural analyses were performed using the facilities of the Biodiversite et Biotechnologies Marines" platform at the University of Perpignan (Bio2Mar, http://bio2mar.obs-banyuls.fr/fr/index.html).

Author Contributions: France Boyaud, Louis Bornancin, and Zahia Mahiout performed the experiments; France Boyaud, Louis Bornancin, Zahia Mahiout, Isabelle Bonnard, Bernard Banaigs, and Nicolas Inguimbert 
analyzed the data; Isabelle Bonnard, Suzanne Mills, Bernard Banaigs, and Nicolas Inguimbert designed the research and wrote the paper.

Conflicts of Interest: The authors declare no conflict of interest.

\section{References}

1. Burja, A.M.; Banaigs, B.; Abou-Mansour, E.; Grant Burgess, J.; Wright, P.C. Marine cyanobacteria-A prolific source of natural products. Tetrahedron 2001, 57, 9347-9377.

2. Moore, R.E. Cyclic peptides and depsipeptides from cyanobacteria: A review. J. Ind. Microbiol. 1996, 16, 134-143.

3. Tan, L.T. Filamentous tropical marine cyanobacteria: A rich source of natural products for anticancer drug discovery. J. Appl. Phycol. 2010, 22, 659-676.

4. Condurso, H.L.; Bruner, S.D. Structure and noncanonical chemistry of nonribosomal peptide biosynthetic machinery. Nat. Prod. Rep. 2012, 29, 1099.

5. Sieber, S.A.; Marahiel, M.A. Molecular mechanisms underlying nonribosomal peptide synthesis: Approaches to new antibiotics. Chem. Rev. 2005, 105, 715-738.

6. Engene, N.; Choi, H.; Esquenazi, E.; Rottacker, E.C.; Ellisman, M.H.; Dorrestein, P.C.; Gerwick, W.H. Underestimated biodiversity as a major explanation for the perceived rich secondary metabolite capacity of the cyanobacterial genus Lyngbya. Environ. Microbiol. 2011, 13, 1601-1610.

7. Banaigs, B.; Bonnard, I.; Witczak, A.; Inguimbert, N. Marine peptide secondary metabolites. In Outstanding Marine Molecules; Barre, S.L., Kornprobst, J.-M., Eds.; Wiley-VCH Verlag GmbH \& Co. KGaA: Weinheim, Germany 2014; pp. 285-318.

8. Frankmölle, W.P.; Knübel, G.; Moore, R.E.; Patterson, G.M. Antifungal cyclic peptides from the terrestrial blue-green alga Anabaena laxa. II. Structures of laxaphycins A, B, D and E. J. Antibiot. (Tokyo) 1992, 45, 1458-1466.

9. Bonnard, I.; Rolland, M.; Salmon, J.-M.; Debiton, E.; Barthomeuf, C.; Banaigs, B. Total structure and inhibition of tumor cell proliferation of Laxaphycins. J. Med. Chem. 2007, 50, 1266-1279.

10. MacMillan, J.B.; Ernst-Russell, M.A.; de Ropp, J.S.; Molinski, T.F. Lobocyclamides A-C, Lipopeptides from a cryptic cyanobacterial mat containing Lyngbya confervoides. J. Org. Chem. 2002, 67, 8210-8215.

11. Luo, S.; Krunic, A.; Kang, H.-S.; Chen, W.-L.; Woodard, J.L.; Fuchs, J.R.; Swanson, S.M.; Orjala, J. Trichormamides A and B with antiproliferative activity from the cultured freshwater cyanobacterium Trichormus sp. UIC 10339. J. Nat. Prod. 2014, 77, 1871-1880.

12. Luo, S.; Kang, H.-S.; Krunic, A.; Chen, W.-L.; Yang, J.; Woodard, J.L.; Fuchs, J.R.; Cho, S.H.; Franzblau, S.G.; Swanson, S.M.; Orjala, J. Trichormamides C and D, antiproliferative cyclic lipopeptides from the cultured freshwater cyanobacterium cf. Oscillatoria sp. UIC 10045. Bioorg. Med. Chem. 2015, 23, 3152-3162

13. Maru, N.; Ohno, O.; Uemura, D. Lyngbyacyclamides A and B, novel cytotoxic peptides from marine cyanobacteria Lyngbya sp. Tetrahedron Lett. 2010, 51, 6384-6387.

14. Zhaxybayeva, O.; Gogarten, J.P.; Charlebois, R.L.; Doolittle, W.F.; Papke, R.T. Phylogenetic analyses of cyanobacterial genomes: Quantification of horizontal gene transfer events. Genome Res. 2006, 16, 1099-1108.

15. Pennings, S.C.; Pablo, S.R.; Paul, V.J. Chemical defenses of the tropical, benthic marine cyanobacterium Hormothamnion enteromorphoides: Diverse consumers and synergisms. Limnol. Oceanogr. 1997, 42, 911-917.

16. Boyaud, F.; Mahiout, Z.; Lenoir, C.; Tang, S.; Wdzieczak-Bakala, J.; Witczak, A.; Bonnard, I.; Banaigs, B.; Ye, T.; Inguimbert, N. First total synthesis and stereochemical revision of laxaphycin B and its extension to Lyngbyacyclamide A. Org. Lett. 2013, 15, 3898-3901.

17. Pedersen, S.L.; Tofteng, A.P.; Malik, L.; Jensen, K.J. Microwave heating in solid-phase peptide synthesis. Chem. Soc. Rev. 2012, 41, 1826-1844.

18. Collins, J.M.; Porter, K.A.; Singh, S.K.; Vanier, G.S. High-efficiency solid phase peptide synthesis (HE-SPPS). Org. Lett. 2014, 16, 940-943.

19. Ben Haj Salah, K.; Inguimbert, N. Efficient microwave-assisted one shot synthesis of peptaibols using inexpensive coupling reagents. Org. Lett. 2014, 16, 1783-1785.

20. Ben Haj Salah, K.; Legrand, B.; Das, S.; Martinez, J.; Inguimbert, N. A straightforward strategy to substitute amide bonds by 1,2,3 triazoles in peptaibols analogs using Aib $\psi[\mathrm{Tz}]-X a a$ dipeptides. Pept. Sci. 2015, 104, 611-621. 
21. White, C.J.; Yudin, A.K. Contemporary strategies for peptide macrocyclization. Nat. Chem. 2011, 3, 509-524.

22. Davies, J.S. The cyclization of peptides and depsipeptides. J. Pept. Sci. 2003, 9, 471-501.

23. Malesevic, M.; Strijowski, U.; Bächle, D.; Sewald, N. An improved method for the solution cyclization of peptides under pseudo-high dilution conditions. J. Biotechnol. 2004, 112, 73-77.

24. Echalier, C.; Al-Halifa, S.; Kreiter, A.; Enjalbal, C.; Sanchez, P.; Ronga, L.; Puget, K.; Verdié, P.; Amblard, M.; Martinez, J.; Subra, G. Heating and microwave assisted SPPS of C-terminal acid peptides on trityl resin: The truth behind the yield. Amino Acids 2013, 45, 1395-1403.

25. Kates, S.A.; Solé, N.A.; Johnson, C.R.; Hudson, D.; Barany, G.; Albericio, F. A novel, convenient, three-dimensional orthogonal strategy for solid-phase synthesis of cyclic peptides. Tetrahedron Lett. 1993, $34,1549-1552$.

26. El-Faham, A.; Funosas, R.S.; Prohens, R.; Albericio, F. COMU: A safer and more effective replacement for benzotriazole-based uronium coupling Reagents. Chem. Eur. J. 2009, 15, 9404-9416.

27. Del Fresno, M.; Alsina, J.; Royo, M.; Barany, G.; Albericio, F. Solid-phase synthesis of diketopiperazines, useful scaffolds for combinatorial chemistry. Tetrahedron Lett. 1998, 39, 2639-2642.

28. Subirós-Funosas, R.; Prohens, R.; Barbas, R.; El-Faham, A.; Albericio, F. Oxyma: An efficient additive for peptide synthesis to replace the benzotriazole-based HOBt and HOAt with a lower risk of explosion ${ }^{[1]}$. Chem. Eur. J. 2009, 15, 9394-9403.

29. Buron, F.; Turck, A.; Plé, N.; Bischoff, L.; Marsais, F. Towards a biomimetic synthesis of barrenazine A. Tetrahedron Lett. 2007, 48, 4327-4330.

30. Boyaud, F.; Viguier, B.; Inguimbert, N. Synthesis of a protected derivative of ( $2 R, 3 R)-\beta$-hydroxyaspartic acid suitable for Fmoc-based solid phase synthesis. Tetrahedron Lett. 2013, 54, 158-161.

31. Hale, K.J.; Manaviazar, S.; Delisser, V.M. A practical new asymmetric synthesis of $(2 S, 3 S)$ - and (2R,3R)-3-hydroxyleucine. Tetrahedron 1994, 50, 9181-9188.

32. Zhang, C.; Kong, L.; Liu, Q.; Lei, X.; Zhu, T.; Yin, J.; Lin, B.; Deng, Z.; You, D. In vitro characterization of echinomycin biosynthesis: Formation and hydroxylation of L-tryptophanyl-S-enzyme and oxidation of $(2 S, 3 S)$ beta-hydroxytryptophan. PLoS ONE 2013, 8, e56772.

33. Cryle, M.J.; Meinhart, A.; Schlichting, I. Structural characterization of OxyD, a cytochrome P450 involved in beta-hydroxytyrosine formation in cancomycin biosynthesis. J. Biol. Chem. 2010, 285, 24562-24574.

34. Uhlmann, S.; Suessmuth, R.D.; Cryle, M.J. Cytochrome P450(sky) Interacts directly with the nonribosomal peptide synthetase to generate three amino acid precursors in skyllamycin biosynthesis. Acs Chem. Biol. 2013, 8, 2586-2596.

35. Mareš, J.; Hájek, J.; Urajová, P.; Kopecký, J.; Hrouzek, P. A hybrid non-ribosomal peptide/polyketide synthetase containing fatty-acyl ligase (FAAL) synthesizes the $\beta$-amino fatty acid lipopeptides Puwainaphycins in the cyanobacterium Cylindrospermum alatosporum. PLoS ONE 2014, 9, e111904.

36. Hoefler, B.C.; Gorzelnik, K.V.; Yang, J.Y.; Hendricks, N.; Dorrestein, P.C.; Straight, P.D. Enzymatic resistance to the lipopeptide surfactin as identified through imaging mass spectrometry of bacterial competition. Proc. Natl. Acad. Sci. USA 2012, 109, 13082-13087.

37. Di Blasio, B.; del Duca, V.; Lombardi, A.; Pedone, C.; Lorenzi, G.P.; Benedetti, E. Conformation and structure of linear peptides with regularly alternating L- and D-residues: Structure of the blocked hexapeptide Tert-butyloxycarbonyl-(D-alloisoleucyl-L-isoleucyl)3 methyl ester monohydrate. Int. J. Pept. Protein Res. 1995, 45, 100-105.

38. Clark, T.D.; Buriak, J.M.; Kobayashi, K.; Isler, M.P.; McRee, D.E.; Ghadiri, M.R. Cylindrical $\beta$-sheet peptide assemblies. J. Am. Chem. Soc. 1998, 120, 8949-8962.

39. Jensen, K.J.; Alsina, J.; Songster, M.F.; Vágner, J.; Albericio, F.; Barany, G. Backbone amide linker (BAL) strategy for solid-phase synthesis of C-terminal-modified and cyclic peptides. J. Am. Chem. Soc. 1998, 120, $5441-5452$.

2015 by the authors; licensee MDPI, Basel, Switzerland. This article is an open access article distributed under the terms and conditions of the Creative Commons by Attribution (CC-BY) license (http://creativecommons.org/licenses/by/4.0/). 